\title{
Review of the Andean armored catfishes of the genus Dolichancistrus Isbrücker (Siluriformes: Loricariidae)
}

\author{
Gustavo A. Ballen ${ }^{1}$ and Richard P. Vari ${ }^{2}$
}

The loricariid catfish genus Dolichancistrus is reviewed and four species recognized. Species of Dolichancistrus are distinguished from each other by the degree of development of the pectoral-fin spine, the form of the distal margin of the pelvic fin, the relative size and form of the cheek plates, the pattern of odontodes along the margin of the snout, the presence versus absence of a buccal papilla at the premaxillary symphysis, and the relative lengths of the anal-versus pelvic-spines. Dolichancistrus atratoensis is known from the río Atrato system and the río Cubarradó on the Pacific versant of Colombia; $D$. carnegiei occurs in the eastern río Magdalena basin in the departments of Boyacá and Santander, Colombia; D. cobrensis inhabits southern tributaries of the Lago Maracaibo basin in Colombia and Venezuela along with some highland rivers of the Cordillera de Mérida in Venezuela draining into the río Orinoco system; and $D$. fuesslii is known from the Andean piedmont portions of the río Meta basin in the western río Orinoco system. Pseudancistrus pediculatus is considered a junior synonym of Ancistrus fuesslii. Chaetostomus setosus previously assigned to Dolichancistrus, was found to lack features characteristic of its putative congeners and is rather more closely related to other members of Chaetostoma group. Consequently, the species is herein considered as incertae sedis within that group. Dolichancistrus is diagnosed, a key is provided to the members of the genus, and diagnoses and redescriptions are provided for all of the recognized species.

Se presenta una revisión del género Dolichancistrus y se reconocen cuatro especies válidas. Las especies de Dolichancistrus se distinguen entre sí a partir del grado de desarrollo de la espina pectoral, la forma del margen distal de la aleta pélvica, el tamaño relativo y la forma de las placas operculares, el patrón de odontoides a lo largo del margen del hocico, la presencia versus ausencia de papila bucal en la sínfisis de las premaxilas, y las longitudes relativas de las espinas anal y pélvicas. Dolichancistrus atratoensis es conocido del sistema del río Atrato y del río Cubarradó sobre la vertiente Pacífico de Colombia; $D$. carnegiei se encuentra en la vertiente Oriental de la cuenca del río Magdalena en los departamentos de Boyacá y Santander, Colombia; $D$. cobrensis habita los tributarios sureños de la cuenca del Lago Maracaibo en Colombia y Venezuela así como en algunos ríos de alta montaña de la Cordillera de Mérida en Venezuela drenando hacia el sistema del río Orinoco; y D. fuesslii es conocido de porciones pedimontanas Andinas de la cuenca del río Meta en la región occidental del sistema del río Orinoco. Pseudancistrus pediculatus es considerado un sinónimo junior de Ancistrus fuesslii. Chaetostomus setosus, una especie previamente considerada dentro del género Dolichancistrus, carece de los caracteres diagnósticos de sus congéneres putativos y es considerada como más cercanamente relacionada con otros miembros del grupo Chaetostoma. Consecuentemente, esta especie es considerada como incertae sedis dentro del grupo Chaetostoma. Dolichancistrus es diagnosticado, y se presenta una clave para sus especies, así como diagnosis y redescripciones para todas las especies reconocidas actualmente dentro del género.

Key words: Andes, Chaetostoma group, Chaetostomus setosus, Northwestern South America.

\section{Introduction}

Armored catfishes of the loricariid genus Dolichancistrus Isbrücker are moderate-sized species dwelling in Andean piedmont and mid-elevation river systems of central and northern Colombia and northwestern Venezuela. The first-named species eventually assigned to the genus was described by Boulenger (1887) as Chaetostomus setosus based on two specimens from an unspecified location in the Andes of Colombia. Steindachner (1911) subsequently proposed Ancistrus fuesslii from eastern Colombia. Soon thereafter Eigenmann $(1916,1917)$ described Pseudancistrus carnegiei from the río Magdalena system and $P$. pediculatus from the upper río Meta system

${ }^{1}$ Universidad Nacional de Colombia, Grupo Cladistica Profunda y Biogeografia Historica, Instituto de Ciencias Naturales, Apartado Aéreo 7495, Bogotá, Colombia.gaballench@gmail.com; gaballench@unal.edu.co

${ }^{2}$ National Museum of Natural History, Division of Fishes, Department do Vertebrate Zoology, MRC-159, PO Box 37012, Smithsonian Institution, Washington, D.C. 20013-7012. varir@si.edu 
in eastern Colombia. Schultz (1944) continued the use of Pseudancistrus Bleeker for species now in Dolichancistrus with his description of a new subspecies, Pseudancistrus pediculatus cobrensis, from the río Cobre, a southwestern tributary of the Lago Maracaibo system. That pattern of generic assignment was continued by Dahl (1960) who described $P$. atratoensis from the río Atrato in northwestern Colombia.

Dolichancistrus was proposed by Isbrücker (1980) in his catalogue of the species of the Loricariidae. In that compendium, Isbrücker assigned three species, Pseudancistrus atratoensis, $P$. cobrensis, and P. pediculatus to Dolichancistrus, with $P$. pediculatus as the type species. In a subsequent summary listing of loricariid species, Isbrücker (2001) expanded Dolichancistrus to encompass Ancistrus fuesslii, Chaetostomus setosus, and Pseudancistrus carnegiei, all previously assigned by Isbrücker (1980) to Lasiancistrus Regan. Isbrücker's actions were within the context of broad taxonomic summaries across the Loricariidae rather than derived from revisionary and/or phylogenetic studies focused on Dolichancistrus. Consequently, he neither delved into the question of the definable species in Dolichancistrus, nor analyzed their distinguishing features and geographic distributions. Indeed, given the limited available samples of Dolichancistrus it is unlikely that Isbrücker examined material of several nominal species. Summaries by Fisch-Muller (2003) and Ferraris (2007) followed Isbrücker (2001) and recognized D. atratoensis, D. carnegiei, $D$. cobrensis, $D$. fuesslii, $D$. pediculatus, and $D$. setosus as valid.

Multiple impediments complicated a resolution of the species-level questions in Dolichancistrus. Species were typically described from a limited type series, in one case a unique holotype and in another instance from two syntypes with inexact type locality information. Diagnoses in the original descriptions of the species assigned to Dolichancistrus were either lacking or brief and often uninformative and the features purposed to delimit the genus were not evaluated across all nominal species. In order to resolve these issues, we examined material including type series of all nominal species of Dolichancistrus across the generic range. We herein diagnose and redescribe Dolichancistrus, evaluate the recognizable species in the genus and redescribe each of them.

\section{Material and Methods}

Counts and measurements follow Armbruster (2003) and institutional acronyms for examined samples are as follows: Auburn University Museum, Auburn (AUM), Academy of Natural Sciences of Philadelphia, Philadelphia (ANSP), Natural History Museum, London (BMNH), California Academy of Sciences, San Francisco (CAS), Private Collection Carlos Ardila Rodriguez's, Barranquilla (CAR), Colección de Ictiología de la Universidad de Antioquia, Medellín (CIUA), Colección de Peces de la Universidad
Católica de Oriente, Rionegro (CP-UCO), Colección de Zoología de la Universidad del Tolima, Tolima (CZUT-IC), Field Museum of Natural History, Chicago (FMNH), Instituto Alexander von Humboldt, Villa de Leyva (IAvHP), Instituto de Ciencias Naturales, Bogotá (ICNMHN), Indiana University (IU, collections now largely at CAS), Instituto Nacional de Pesquisas da Amazônia, Manaus (INPA), Museo de Biología de la Universidad Central de Venezuela, Caracas (MBUCV-V), Museo de Ciencias Naturales de UNELLEZ, Guanare (MCNG), Museo de Historia Natural de La Salle, Bogotá (MLS), Muséum national d'Histoire Naturelle, Paris (MNHN), Museo de la Universidad de San Marcos, Lima (MUSM), Naturhistorisches Museum, Wien (NMW), National Museum of Natural History, Smithsonian Institution, Washington (USNM), and Zoölogisch Museum, Universiteit van Amsterdam, Amsterdam (ZMA). Abbreviations in the text are c\&s [cleared and stained specimens prepared following Taylor \& van Dyke (1985) with modifications], masl (elevation in meters above sea level) and SL (standard length). In the lists of material examined, the museum acronym and catalogue number are followed by the number of specimens in the lot with the parenthetical information indicating the number of specimens from which counts and measurements were taken (when different than the total number of specimens) and the range of their standard lengths. This is followed by locality information clustered to the degree possible by geographic proximity.

Although the species of Dolichancistrus differ from each other in various features, they share very similar overall external morphologies of the head, body and unpaired fins. In light of that overall uniformity, we provide a general description for all members of the genus, with individual species accounts focusing on details of the head, body, pectoral fin, pelvic fin, odontodes, and pigmentation that differ among species with these data complemented by species-specific supplementary information. Dorsal-fin ray formula includes the dorsal-fin anterior spinelet as an unbranched fin ray. Specimens displaying secondary sexual dimorphism (primarily in the condition of the genital papilla) are reported as mature. Osteological nomenclature follows Geerinckx \& Adriaens (2006) and Geerinckx et al. (2007) with the exception of the use of cheek odontodes rather than cheek spines (e.g., Armbruster, 2008) in order to be consistent with the histology of these structures. In keeping with the general practice in descriptions of loricariids (e.g., Lujan et al., 2009), we use the term spine for the leading element of the anal, pectoral, and pelvic fins, the second unbranched ray of the dorsal fin, and the ventralmost and dorsalmost unbranched rays of the caudal fin. The concept of Chaetostoma Tschudi follows Armbruster (2004a), which is the only published phylogenetic framework for the genus. Chaetostoma in that sense differs from traditional concept of the genus (e.g., Provenzano \& Milani, 2006) both in diagnostic features and included species. 


\section{Dolichancistrus Isbrücker, 1980}

Dolichancistrus Isbrücker, 1980: 47 [type species: Pseudancistrus pediculatus Eigenmann, 1918; herein subjective synonym of Ancistrus fuesslii Steindachner, 1911. Type by original designation].

Diagnosis. Dolichancistrus is a member of the Chaetostoma group (sensu Armbruster 2004a, 2008) differentiated in that group from Leptoancistrus Meek \& Hildebrand by the presence of the adipose and anal fins (vs. the absence of both fins); from Cordylancistrus and Chaetostoma (sensu Armbruster, 2004a) by the presence of pectoral-fin spines in mature males longer than those in adult females and immatures of both sexes (vs. the pectoral spines of equal length in both sexes); and from the species of Chaetostoma except for $C$. platyrhynchus (Fowler) in having a plated snout (vs. naked). Dolichancistrus differs from Chaetostoma platyrhynchus in having the hyperthrophied cheek odontodes evertible to more than $90^{\circ}$ (vs. evertible only to approximately $30-40^{\circ}$ ) and in bearing hyperthrophied cheek odontodes that are distally recurved (vs. odontodes straight along their entire length). More broadly within the Ancistrini, Dolichancistrus is externally distinguishable from Acanthicus Spix \& Agassiz, Leporacanthicus Isbrücker \& Nijssen, Megalancistrus Isbrücker and Pseudacanthicus Bleeker in the absence of keeled plates on the lateral surface of the body vs. the presence of keeled plates); from Ancistrus Kner, Dekeyseria Rapp Py-Daniel, Lasiancistrus Regan, Lithoxus Eigenmann, Neblinichthys Ferraris, Isbrücker \& Nijssen and Pseudolithoxus Isbrücker \& Nijssen in possessing five series of plates on the caudal peduncle ( $v s$. three series of plates on the caudal peduncle); from Baryancistrus Rapp Py-Daniel, Parancistrus Bleeker, and Spectracanthicus Nijssen \& Isbrücker by having the dorsal-fin membrane on the posteriormost dorsal-fin ray extending along the dorsal margin of the body for only a short distance (vs. an enlarged portion of the membrane extending from the fin posteriorly to the preadipose plate); from Exastilithoxus Isbrücker \& Nijssen by the absence of fimbriae on the margin of the mouth (vs. with lips bearing fimbriae); from Hopliancistrus Isbrücker \& Nijssen by having long cheek odontodes that are straight for most of their length and recurve only distally (vs. short cheek odontodes which are strongly recurved from the base to the tip); from Hypancistrus Isbrücker \& Nijssen and Micracanthicus Lujan \& Armbruster by having the teeth on the dentary and premaxilla of approximately the same length (vs. dentary teeth longer than those on the premaxilla); from Panaque Eigenmann \& Eigenmann by the presence of elongate, distally-recurved, and slender-cusped teeth on the jaws (vs. strong, spoon-shaped teeth at least in adults) and premaxillae positioned in an approximately straight line ( $v s$. an angle between the premaxillae about $30^{\circ}$ ); from Paulasquama Armbruster \& Taphorn by having the plates on the snout and the dorsal series of lateral body plates well developed (vs. weakly developed) and in having the pectoral- fin spine always reaching at least to the insertion of the pelvic fin at least in males (vs. never reaching the pelvic insertion); and from Soromonichthys Lujan \& Armbruster in bearing plates over all of the snout (vs. snout without plates along on its margins and along the midline). Notwithstanding the uncertainty about the diagnosability of Hemiancistrus, Peckoltia, and Pseudancistrus (Armbruster, 2004b, 2008), Dolichancistrus is separable from those genera as currently recognized in having the medial hyperthrophied cheek odontodes thicker than the outer odontodes (vs. all the odontodes equally thick).

Description. Medium-sized loricariids, with largest examined specimen $153.7 \mathrm{~mm}$ SL (a male of Dolichancistrus carnegiei). Head and body strongly depressed and moderately wide. Lateral profile of anterior portion of head gently convex from tip of snout to vertical through posterior nares, then nearly straight to dorsal-fin insertion. Dorsal profile of body straight to very slightly posteroventrally angled from terminus of dorsal-fin base to insertion of dorsal caudal-fin spine. Ventral profile of head and body straight to very slightly convex to insertion of ventral caudal-fin spine.

Supraorbital bony ridge absent, with interorbital area ranging transversely from slightly convex to flat. Ridge of hypertrophied odontodes present in adults in region from anterior portion of orbit to anteroventral portion of nares; degree of development of ridge interspecifically and ontogenetically variable. Medial region from tip of snout to nares with distinct hypertrophied odontodes; odontodes usually more obvious in mature males but variably developed interspecifically. Profile of head smoothly rounded anteriorly in dorsal view other than for odontodes extending in adults along anterior and lateral margins of snout. Hypertrophied odontodes along lateral margin of snout extending posteriorly for variable distances, but never reaching plates immediately anterior to cheek plates.

Cheek with two to ten extremely hypertrophied odontodes supported by skin-covered, bony ossicles (sensu Geerinckx \& Adriaens, 2006) plus several shorter albeit lengthened odontodes supported by outer exposed cheek plates. Hypertrophied cheek odontodes distally recurved with largest fully developed odontode extending posterior of base of first or second branched pectoral-fin ray. Cheek plates in two series. Dorsal series with two large plates varying in orientation, shape, and size among species. Ventral series with three or four smaller plates usually either lacking odontodes or with odontodes mostly covered by thick skin. Frontal, infraorbital, nasal, opercle, compound pterotic, sphenotic, and parieto-supraoccipital bones supporting odontodes of various sizes. Opercular odontodes present on exposed portion of opercle, with odontodes along opercular margin frequently larger than those on exposed surface of opercle. Cheek, snout and pectoral-spine odontodes surrounded basally by fleshy collar and most often with small lateral papilla as in Dekeyseria (Sabaj et al., 1999, fig. 4b). 
Fleshy papillae present when odontodes not fully developed. Odontodes on pectoral spine longer than associated papillae.

All series of lateral plates other than ventral series complete and extending from compound pterotic to posterior limit of caudal peduncle. Body plates without keels, but plates of ventral series with slight flexion midway along their vertical extent forming discrete angle along ventrolateral margin of caudal peduncle. Ventral plate series incomplete anteriorly with first plate located anterior of pelvic-fin insertion. Five series of plates present on caudal peduncle. Abdomen naked. First anal-fin pterygiophore not exposed to form plate-like structure.

Tip of adpressed dorsal fin extending posteriorly to terminate within area short of, to slightly beyond, anterior margin of preadipose plate. Dorsal-fin spine stiff basally, flexible distally and not extending beyond distal margin of fin. Margin of fin ranges from straight to slightly convex. Exposed margin of dorsal-fin spinelet moderately convex and variably covered by skin. Dorsal-fin spine lock functional. Adipose-fin spine of moderate length and bearing odontodes. Distal margin of caudal fin ranging from slightly emarginate to obliquely straight, with form variable both intraspecifically and ontogenetically. Ventral lobe of caudal fin longer than dorsal lobe. Anal-fin base short, usually about one-third length of second unbranched analfin ray. Tip of adpressed anal fin extending posteriorly to, or nearly to, vertical through adipose-fin origin. Length of pectoral-fin spine highly variable interspecifically but longer in mature males than mature females of all species. Tip of adpressed pectoral-fin spine falling between mid-length of adpressed pelvic-fin spine and point beyond tip of spine in mature males, and between insertion and tip of pelvic-fin spine in mature females. Pectoral-fin spine in mature males with hypertrophied odontodes extending along distal onefifth to one-fourth of dorsolateral surface. Single series of odontodes present on dorsal surface of pectoral-fin spine in mature specimens regardless of sex or maturity. Distal margin of pectoral fin sigmoid when fully developed in adults, with margin convex medially and gently concave distally. Tip of adpressed pelvic fin reaching posteriorly to beyond anal-fin insertion. Dorsal surface of spine usually lacking odontodes. Form of posterior margin of pelvic fin interspecifically variable. Immature individuals of both sexes with distal fin margin straight whereas larger specimens with distal margin either W-shaped or convex.

Iris operculum present. Short, fleshy flap with round margin present between anterior and posterior nares. Lips wide and fairly thick. Upper lip with multiple series of papillae. Papillae proximate to mouth opening small and rounded and preceded anteriorly first by larger papillae and then by more elongate papillae along lip margin. Lower lip with medium-sized round papillae anteriorly and smaller ones posteriorly but with skin near posterior margin of lip nearly smooth. Lip border crenate. Maxillary barbel short, separate from lower lip distally but variably fused to lip basally in some specimens and extending up to one-half distance to transverse line along posteriormost limit of lower lip. Median buccal papilla present posterior of symphysis of premaxillae in all but one species.

Jaws wide transversely. Dentaries meeting at variably oblique angle ranging from nearly straight line to distinct angle with variation apparently artifact of preservation. Anterior margin of premaxilla forming nearly straight line. Dentary larger than premaxilla. Peduncles of teeth fairly long, narrow and distally recurved. Cusps asymmetrically developed with lateral tooth cusp approximately one-half length of medial cusp. Dentary teeth 30-100 and premaxillary teeth 20-70; number of teeth on each ramus increasing ontogenetically.

Sexual dimorphism. Mature females have a greatly widened, pad-like genital papilla with some transverse flaps at the papillary opening. The aperture of the genital papilla in mature females is located proximate to, but separate from, the opening of the vent. Mature males have a distinctly-pointed genital papilla with a distal aperture. Mature males also typically demonstrate a greater degree of development of the odontodes along the margin of the snout and medial region of head from the tip of the snout to the nares, and in the area between the orbit and the nares. The pectoral-fin spines and distal odontodes on the spines are proportionally longer in mature males than in mature females. Males of all species achieve greater standard lengths than do conspecific females and also reach maturity at larger overall sizes.

Distribution. Species of Dolichancistrus are known from eastern tributaries of the río Atrato at elevations of 460 to 1380 masl, the río Cubarradó a small coastal drainage south of the Serranía de Baudó on the Pacific Ocean versant, the middle portions of the eastern río Magdalena basin along the Cordillera Oriental between approximately 500 and 2540 masl, western portions of the río Orinoco basin on the slopes and piedmont of the Cordillera Oriental from the Serranía de la Macarena to the río San Antonio in Venezuela at elevations of approximately 500 to 2500 masl and southeastern tributaries of the lago Maracaibo basin in Colombia and Venezuela. Samples with specific locality information indicate that all species are allopatrically distributed. A few samples with inexact locality data that include two species likely represent geographically complex series of specimens (see Remarks for D. carnegiei).

Generic placement of Chaetostomus setosus. Chaetostomus setosus, the first described species eventually assigned to Dolichancistrus, was proposed by Boulenger (1887: 349). This species was shifted to Pseudancistrus Bleeker by Eigenmann and Eigenmann (1890: 435), whereas Regan (1904: 3239) assigned it to the subgenus Pseudancistrus within Ancistrus Kner. Fowler (1942: 132) followed Eigenmann \& Eigenmann (1890) in recognizing the species within Pseudancistrus. Isbrücker (1980: 46) first shifted the species to Lasiancistrus and 
then to Dolichancistrus (2001: 27) without any comment; a practice continued by subsequent authors.

Isbrücker (1980: 47) identified one putative diagnostic feature for Dolichancistrus, "the possession of very long interopercular odontodes [= hypertrophied cheek odontodes], extending much beyond the head in the adult male" (comments in brackets ours). The two or more greatly hypertrophied and distally-recurved cheek odontodes reaching distinctly beyond the pectoral-spine origin in $D$. atratoensis, $D$. carnegiei, $D$. cobrensis, and $D$. fuesslii, as well as in Leptoancistrus likely represent the cited condition. Elongation of cheek odontodes in Dolichancistrus (exclusive of Chaetostomus setosus) and Leptoancistrus also occurs in some other ancistrin genera (e.g., Acanthicus, Cordylancistrus, Hemiancistrus, and Panaque), sometimes to a degree comparable to that in Dolichancistrus and Leptoancistrus. Chaetostomus setosus, conversely, has proportionally distinctly shorter, albeit hypertrophied, cheek odontodes that fall short of, or barely reach, the pectoral-fin spine origin.

Proportionally longer pectoral-fin spines of mature males relative to mature females and immature specimens of both sexes were also proposed as diagnostic for Dolichancistrus (Armbruster, 2004: 37). Such dimorphism does indeed occur in Dolichancistrus atratoensis, $D$. carnegiei, D. cobrensis, D. fuesslii, and species of Leptoancistrus but is absent in Chaetostomus setosus. Sexually dimorphic pectoral spines of this type are limited to Leptoancistrus and Dolichancistrus (other than for Chaetostomus setosus) in the Ancistrini and support the hypothesis of a sister-group relationship for Dolichancistrus plus Leptoancistrus but excluding Chaetostomus setosus.

Removal of Chaetostomus setosus from Dolichancistrus is appropriate based on the phylogenetic evidence that a more restricted Dolichancistrus is the sister group to Leptoancistrus. As a side benefit, this makes Dolichancistrus readily diagnosable externally. The question is then one of the appropriate generic placement of the species. Chaetostomus setosus shares a supraoccipital dermal ridge with components of both Chaetostoma (Salcedo, 2006) and Cordylancistrus (pers. obs.) but not Dolichancistrus and Leptoancistrus. This ridge is hypothesized as derived given its absence across the remainder of the Chaetostoma group indicating that the relationship of Chaetostomus setosus lies with components of Chaetostoma or Cordylancistrus. The absence of resolution about relationships within the Chaetostoma group complicates the assignment of Chaetostomus setosus to either Chaetostoma or Cordylancistrus with the non-monophyly of Cordylancistrus in the sense of Provenzano \& Milani (2006) in subsequent analyses (e.g., Armbruster, 2008) problematic. In light of those complications, we place Chaetostomus setosus as incertae sedis within the Chaetostoma group.
Type locality for Chaetostomus setosus. Although we exclude Chaetostomus setosus from Dolichancistrus, our investigations were informative as to the likely type region of the species. Boulenger (1887: 349) remarked that the types of Chaetostomus setosus were part of "a small collection of fishes made by F. A. Simons in Colombia (locality not mentioned)." According to Hilty \& Brown (1986: 37), Simons collected birds in northeastern Colombia in the late 1870s apparently in the expeditions that yielded the types of $C$. setosus. Simons (1881) discussed his travels through the region around the Sierra Nevada de Santa Marta, the northern portions of the lower río Magdalena basin and other lowlands west of the Serranía del Perijá. Only two samples of Chaetostomus setosus with detailed locality information were located, both from the río Cesar basin, Departamento de Cesar, west of the Serranía del Perijá (CIUA 698, 4, 51.04$70.82 \mathrm{~mm}$ SL; ICNMHN 1158, 5, 27.39-72.30 mm SL). It is likely that the syntypes originated in that region.

Remarks. Dolichancistrus was purported to be externally distinguishable from other genera in having a pronounced sexual dimorphism in pectoral spine length with the spine of mature males extending beyond the tip of the pelvic fin spine versus the shorter pectoral-fin spine in mature conspecific females. Although dimorphism in pectoralspine length is general across Dolichancistrus, only in $D$. cobrensis and $D$. fuesslii does the tip of the adpressed pectoral-fin spine reach or extend beyond the tip of the adpressed pelvic-fin spine.

Comparable sized conspecific mature males of all species of Dolichancistrus demonstrate striking variation in odontode development and it appears that males shed their hypertrophied snout odontodes seasonally. Armbruster (2004a: 41) noted that members of Dolichancistrus and Leptoancistrus often shed their hypertrophied cheek odontodes although the underlying cause and periodicity was not noted. Seasonal loss of cheek odontodes occurs elsewhere in the Loricariidae in Panaque (pers. obs.; J. W. Armbruster, pers. comm.), Rineloricaria uracantha (Moodie \& Power, 1980: 144; Loricaria uracantha therein) and an apparent periodic shedding of cheek odontodes was observed in Chaetostoma, Cordylancistrus and Leptoancistrus (pers. obs.).

\section{Key to species of Dolichancistrus}

1. Buccal papilla absent at premaxillary symphysis; hypertrophied snout odontodes in mature males and females either restricted to anterolateral regions of snout margin, or weakly developed on narrow anterior region of snout in addition to anterolateral odontode patch present in some specimens ................................. D. cobrensis

1'. Buccal papilla present at premaxillary symphysis; hypertrophied snout odontodes in mature males extending along entire margin of snout and sometimes also onto medial region of head from tip of snout to nares ........... 2 
2. Anterior margin of adpressed posterior dorsal cheek plate medially contacting anterior margin of exposed portion of opercle; tip of adpressed pectoral-fin spine in mature males extending distinctly beyond tip of adpressed pelvic-fin spine and in mature females to tip of pelvic-fin spine D. fuesslii

2'. Anterior margin of adpressed posterior dorsal cheek plate not medially contacting anterior margin of exposed portion of opercle; tip of adpressed pectoral-fin spine in mature males extending to area between middle and tip of adpressed pelvic-fin spine and in mature females reaching to area between base and middle of pelvic-fin spine ...... 3

3. Anterior dorsal cheek plate ventrally triangular and distinctly smaller than posterior check plate in lateral view; length of anal-fin spine less than or nearly equal to one-third length of pelvic-fin spine ................................. D. atratoensis

3'. Anterior dorsal cheek plate square and approximately as large as posterior check plate in lateral view; length of anal-fin spine nearly equaling or exceeding one-half length of pelvic-fin spine ................................... D. carnegiei

\section{Dolichancistrus atratoensis (Dahl, 1960) Fig. 1}

Pseudancistrus atratoensis Dahl, 1960: 455, figs. [Type locality: Colombia, Quebrada La Noche, tributary to upper río Atrato, approximate height above sea level $550 \mathrm{~m}]$.

Dolichancistrus atratoensis Isbrücker, 1980: 47 [shift to Dolichancistrus]. - Burgess, 1989: 434 [in listing of species of the Loricariidae]. - Isbrücker, 2001: 26 [in listing of species of the Loricariidae]. - Isbrücker, 2002: 29 [in listing of species of the Loricariidae]. - Fisch-Muller, 2003: 384 [in checklist of species of the Ancistrinae]. - Maldonado-Ocampo et al., 2005: 153, map 143 [Andes of Colombia, upper río Atrato; summary data; common name]. - Maldonado-Ocampo et al. 2006: 149 [Colombia, río Atrato; misidentified in part]. Ferraris, 2007: 235 [in checklist of catfishes]. - MaldonadoOcampo et al., 2008: 198 [Colombia].

Pseudancistrus atratoensis, Cala, 1981: 3 [type depository]. Mojica \& Castellanos-C, 2007: 84 [type repository; type locality erroneously cited as in Município Riosucio, Departamento de Antioquia, see Remarks].

Material examined. All collections from Colombia. CIUA 768, 1, 120.3 mm SL, Departamento de Antioquia, río Atrato drainage, Urrao, vereda Calles, Quebrada La Selva, 1365 masl. CIUA 769, 2, 92.9-111.6 mm SL, Departamento de Antioquia, río Atrato drainage, Urrao, vereda Calles, quebrada La Crespa, 1346 masl, 6³1'10”N, 76¹7’05.1”W. CIUA 771, 1, 114.6 mm SL, Departamento de Antioquia, río Atrato drainage, Frontino, vereda Venados, río Venados, 824 masl, 6³2’22.5”N, 76¹9’33.9”W. CIUA 772, 2, 51.0-70.0 mm SL, Departamento de Antioquia, río Atrato drainage, Frontino, vereda Venados, quebrada La Aguada, 1110 masl, 6³3’26.4”N 76¹7'03.8”W. IAvH-P 6630, 1, 63.9 mm SL, Departamento de Chocó, Quibdó, río Tutunendo. ICNMHN 51, holotype, 81.0 mm
SL, male, Departamento de Chocó, Carmen de Atrato, río Atrato, quebrada La Noche, 500 masl. ICNMHN 46, paratypes, 42, 42.0$68.6 \mathrm{~mm}$ SL; erroneously cited as ICNMHN 48 by MaldonadoOcampo et al. (2008), Departamento de Chocó, Carmen de Atrato, río Atrato, Quebradas La Noche and La 16. ICNMHN 74, paratype, 1, $61.1 \mathrm{~mm}$ SL, male, Departamento de Chocó, Carmen de Atrato, río Atrato, Quebradas La Noche and La 16. ICNMHN 3460, 1, 50.9 mm SL, Departamento de Chocó, Pacific Ocean versant, Purrichá, río Cubarradó, quebrada Purrichá.

Diagnosis. Dolichancistrus atratoensis is diagnosable from all congeners in having a unique form of the cheek plates in which the anterior plate is smaller than the posterior plate and has the form of a ventrally oriented triangle from a lateral view (vs. anterior and posterior cheek plates of nearly the same size and square or rectangular from a lateral view, respectively), in having the tip of the adpressed pectoral-fin spine in mature males falling within the area between the base and middle of the adpressed pelvic-fin spine (vs. reaching to the tip of the pelvic-fin spine in $D$. carnegiei, falling slightly short of, to extending somewhat beyond, the tip of the spine in $D$. cobrensis, and far surpassing the tip of the spine in $D$. fuesslii). Dolichancistrus atratoensis is additionally distinguished from $D$. carnegiei in the length of the anal-fin spine (onethird or less vs. one-half or more of the length of the pelvic-fin spine, respectively). Dolichancistrus atratoensis further differs from $D$. cobrensis in the condition of the buccal papilla within the oral cavity at the limit of the symphysis of the premaxillae (present vs. absent, respectively). Dolichancistrus atratoensis can also be differentiated from $D$. fuesslii in the form of the distal margin of the pelvic fin in mature males (either straight or approximately smoothly convex vs. Wshaped, respectively) and in the relationship of the posterior cheek plate with the exposed portion of the opercle (ossifications distinctly separated vs. the margin of the anteromedial corner of the posterior cheek plate in contact with the anterior margin of the exposed portion of the opercle, respectively).

Description. See description under generic account for features common to all species of Dolichancistrus. Largest examined specimen $120.3 \mathrm{~mm}$ SL. Morphometrics presented in Table 1. Dorsal-fin rays ii,8; anal-fin rays ii,3 or 4 [one malformed individual with ii,1]; caudal-fin rays i,14,i; pectoralfin rays i,6; pelvic-fin rays i,5. Preadipose plates 1 -2; median plates 22-25. Buccal papilla present within oral cavity at limit of symphysis of premaxillae. Enlarged odontodes variably present along entire anterior or anterolateral margins of snout (see Sexual dimorphism for comments on variation). Anterior margin of posterior cheek plate distinctly separated from anterior margin of exposed portion of opercle. Anterior cheek plate triangular, obliquely oriented, approximately one-half length of, and positioned largely ventrolateral to, posterior cheek plate. Hypertrophied cheek odontodes distally recurved. Distal margin of pelvic fin straight to convex. Spine of adpressed pectoral fin in mature males reaching posteriorly approximately midway along length of adpressed pelvic fin 
and in mature females approximately to insertion of pelvic fin. Odontodes extending along distal one-half of pectoral-fin spine. Anal fin usually present, but highly reduced in the male and absent in the female of CIUA 772.

Coloration in alcohol. Overall ground coloration of head and body brownish on lateral and dorsal surfaces, lightly pigmented ventrally other than for upper lip. Body pigmentation pattern variable and ranging from unpatterned to highly vermiculated and mottled, sometimes with unpigmented region on ventral portion of caudal peduncle. Variation in color pattern apparently not correlated with age, sex, or breeding condition. Largest examined individual with nearly uniform dark gray coloration over head and body. Dorsal fin with alternating dark and light areas along rays that form irregular, somewhat transverse bar-like pattern along length of fin. Spacing between dark areas variable, but usually of same expanse as width of dark regions. Membranes lack
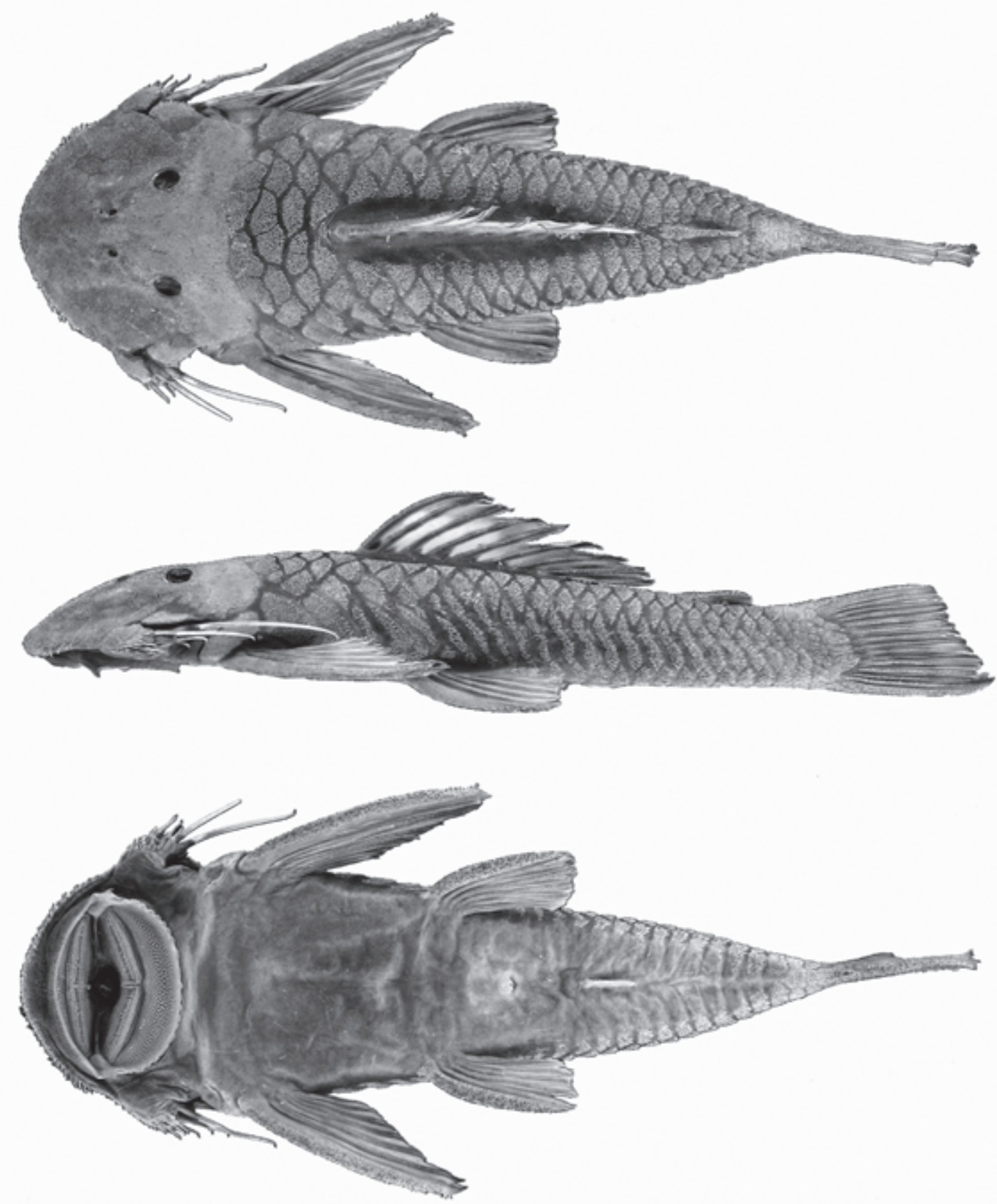

Fig. 1. Dolichancistrus atratoensis, CIUA 768, 120.3 mm SL. Colombia, Departamento de Antioquia, quebrada la Selva; dorsal, lateral and ventral views. 
dark pigmentation. Anal fin with scattered chromatophores covering basal portion of fin rays, but with membranes unpigmented. Caudal fin with alternating dark and light areas along rays that form irregular transverse bar-like pattern across vertical extent of fin. Pectoral-fin spine with alternating dark and light regions on dorsal surface; ventral surface lacking dark pigmentation. Pectoral and pelvic fins with pattern of alternating transverse dark and light pigmentation on lateral rays, with medial rays and all of membranes unpigmented.

Sexual dimorphism. Mature males of Dolichancistrus atratoensis demonstrate greater degrees of development of the odontodes along the margin of the snout, the medial region of head from the tip of the snout to nares and in the area between the orbit and nares than do mature females. The pectoral-fin spine of mature males is proportionally longer than that of mature females.

Distribution. Dolichancistrus atratoensis is known from southeastern tributaries of the río Atrato in northern Colombia along with the río Cubarradó, a small Pacific versant system draining a portion of the southern slope of the Serranía de Baudó in western Colombia (Fig. 2).
Common name. Cacucho, Guacuco (Maldonado-Ocampo et al., 2005: 153).

Remarks. Dahl (1960) identified the holotype of Pseudancistrus atratoensis as a female and the allotype (= paratype) as a male. Examination revealed that both are males with the holotype lacking hypertrophied odontodes despite having an obvious male genital papilla and the elongate pectoral spine characteristic of male congeners. Presumably Dahl's identification of the holotype as a female was based on the absence of hypertrophied odontodes in females of some ancistrin species. As noted above, these odontodes are seasonally absent in males of Dolichancistrus.

Dahl (1960: 455) reported the type locality of Pseudancistrus atratoensis as "quebrada La Noche, tributary to the upper Atrato, approximate height above sea level $550 \mathrm{~m}$ " and that the types were collected on “August $10^{\text {th }}$, 1959." In a compendium of ICNMHN fish types, Mojica \& Castellanos-C (2007: 84), modified this to "Departamento de Antioquia, Riosucio, alto río Atrato, quebrada La Noche, vertiente occidental, Cordillera Occidental, altitud $550 \mathrm{~m}$ ” thereby shifting the locality to a different department. ICNMHN catalog cards indicate Dahl

Table 1. Morphometric data for Dolichancistrus atratoensis $(\mathrm{n}=14), D$. carnegiei $(\mathrm{n}=22), D$. cobrensis $(\mathrm{n}=27)$ and $D$. fuesslii $(\mathrm{n}=41)$. Landmarks follow Armbruster (2003). Standard deviation designated as SD.

\begin{tabular}{|c|c|c|c|c|c|c|c|c|c|c|c|c|}
\hline \multirow[t]{2}{*}{ Measurement } & \multicolumn{3}{|c|}{$\begin{array}{c}\text { Dolichancistrus } \\
\text { atratoensis }\end{array}$} & \multicolumn{3}{|c|}{ D.carnegiei } & \multicolumn{3}{|c|}{ D. cobrensis } & \multicolumn{3}{|c|}{ D. fuesslii } \\
\hline & Range & Mean & SD & Range & Mean & SD & Range & Mean & SD & Range & Mean & SD \\
\hline Standard Length & $42.0-120.3$ & 73.4 & - & $59.4-126.4$ & 83.5 & - & $47.6-92.1$ & 61.1 & - & $32.9-124.4$ & 72.9 & - \\
\hline Predorsal Length & $39.0-46.2$ & 43.8 & 2.0 & $41.9-45.2$ & 43.7 & 0.9 & $42.9-46.5$ & 44.5 & 0.9 & $41.3-47.8$ & 44.3 & 1.5 \\
\hline Head Length & $28.8-37.0$ & 33.5 & 2.2 & $31.4-34.0$ & 32.7 & 0.7 & $30.7-35.0$ & 32.9 & 1.2 & $31.9-36.2$ & 33.7 & 1.1 \\
\hline Head-dorsal Length & $8.3-12.9$ & 10.8 & 1.4 & $7.8-12.5$ & 10.2 & 1.3 & $9.7-12.9$ & 11.7 & 0.8 & $9.1-12.3$ & 10.3 & 0.7 \\
\hline Cleithral Width & $29.3-34.8$ & 32.6 & 1.6 & $31.3-34.3$ & 32.8 & 0.8 & $30.2-33.7$ & 31.9 & 0.9 & $31.4-35.7$ & 33.1 & 1.0 \\
\hline Head-pectoral Len & $26.6-34.1$ & 30.3 & 2.1 & $27.3-31.9$ & 29.7 & 1.2 & $27.6-31.8$ & 29.6 & 1.2 & $28.4-34.2$ & 30.9 & 1.3 \\
\hline Thorax Length & $21.5-25.5$ & 23.3 & 1.0 & $19.8-27.8$ & 24.2 & 2.0 & $20.1-27.2$ & 24.7 & 1.9 & $20.0-25.9$ & 23.0 & 1.6 \\
\hline Pectoral spine Length & $24.7-38.7$ & 30.5 & 4.1 & $30.0-43.1$ & 34.1 & 3.9 & $32.6-42.1$ & 37.6 & 2.6 & $31.5-53.0$ & 40.1 & 1.0 \\
\hline Abdominal Length & $21.1-25.2$ & 22.6 & 1.3 & $21.9-23.8$ & 22.8 & 0.5 & $20.7-25.7$ & 23.8 & 1.2 & $21.9-26.0$ & 23.8 & 0.9 \\
\hline Pelvic spine Length & $16.1-26.0$ & 21.7 & 2.6 & $20.6-24.8$ & 23.4 & 0.9 & $22.1-25.4$ & 23.5 & 0.8 & $20.6-27.1$ & 24.0 & 1.5 \\
\hline Postanal Length & $24.2-31.7$ & 27.7 & 2.5 & $25.4-30.7$ & 29.0 & 1.5 & $25.2-28.5$ & 26.8 & 0.8 & $25.3-30.5$ & 28.0 & 1.1 \\
\hline Anal-fin spine Length & $2.1-7.1$ & 4.6 & 1.9 & $5.6-8.4$ & 6.6 & 0.7 & $3.7-6.4$ & 4.9 & 0.8 & $4.4-8.1$ & 6.6 & 1.0 \\
\hline Dorsal-pectoral Distance & $24.2-28.3$ & 26.5 & 1.1 & $25.5-30.0$ & 27.4 & 1.4 & $25.9-29.1$ & 27.5 & 0.8 & $23.2-29.3$ & 26.8 & 1.5 \\
\hline Dorsal-pelvic Distance & $18.9-24.8$ & 21.4 & 2.0 & $18.3-26.5$ & 21.2 & 2.0 & $16.3-22.4$ & 19.5 & 1.7 & $16.7-23.4$ & 20.5 & 1.3 \\
\hline Dorsal-fin base Length & $20.7-28.9$ & 25.9 & 2.3 & $22.5-25.3$ & 23.8 & 0.7 & $22.1-29.0$ & 25.6 & 1.5 & $21.9-30.9$ & 25.3 & 2.1 \\
\hline Dorsal-adipose Distance & $14.6-17.8$ & 16.3 & 0.9 & $17.0-21.3$ & 19.1 & 1.1 & $14.3-18.6$ & 16.6 & 1.2 & $15.6-22.2$ & 18.0 & 1.7 \\
\hline Adipose spine Length & $6.6-9.1$ & 7.4 & 0.7 & $5.9-8.5$ & 7.1 & 0.7 & $6.8-8.4$ & 7.8 & 0.4 & $6.0-9.0$ & 7.6 & 0.8 \\
\hline Dorsal adipose-caudal D & $10.2-16.8$ & 12.8 & 2.1 & $10.1-14.4$ & 11.9 & 1.0 & $.5-12.7$ & 10.7 & 1.0 & $.5-14.0$ & 11.4 & 1.2 \\
\hline Caud & $9.9-13.1$ & 11.5 & 1.0 & $10.2-13.1$ & 11.1 & 0.7 & $9.3-11.5$ & 10.5 & 0.6 & $9.0-11.5$ & 10.4 & 0.6 \\
\hline Ventral Adipo & $16.3-21.0$ & 18.7 & 1.4 & $16.1-9.9$ & 18.3 & 1.2 & $16.2-18.6$ & 17.8 & 0.5 & $15.4-19.4$ & 17.1 & 0.9 \\
\hline Adipose-anal Distance & $14.0-20.3$ & 17.0 & 1.9 & $14.7-18.8$ & 16.8 & 0.9 & $15.4-18.0$ & 17.0 & 0.8 & $15.0-19.5$ & 17.5 & 1.2 \\
\hline Dorsal-anal Distance & $11.3-15.7$ & 13.7 & 1.4 & $12.1-13.7$ & 13.0 & 0.5 & $12.1-13.8$ & 13.0 & 0.4 & $11.0-14.0$ & 12.8 & 0.8 \\
\hline lorsal Distance & $21.6-29.1$ & 25.2 & 2.1 & $22.1-26.2$ & 24.4 & 1.1 & $23.2-28.0$ & 25.4 & 1.4 & $21.8-42.6$ & 25.8 & 3.1 \\
\hline Head-eye Length & $31.6-41.1$ & 35.5 & 2.6 & $32.2-38.3$ & 35.3 & 1.5 & $32.8-38.8$ & 34.9 & 1.3 & 30.0 - 39.5 & 34.2 & 2.2 \\
\hline Orbit Diameter & $10.9-18.0$ & 14.1 & 2.1 & $9.3-17.3$ & 13.4 & 1.9 & $12.1-17.3$ & 14.0 & 1.5 & $12.1-16.3$ & 14.5 & 1.3 \\
\hline Snout Length & $59.8-70.2$ & 65.9 & 2.6 & $65.5-69.9$ & 67.4 & 1.5 & $59.7-70.6$ & 65.0 & 2.3 & $63.1-69.6$ & 66.8 & 1.5 \\
\hline Internares Width & $16.3-21.3$ & 18.4 & 1.6 & $16.4-19.4$ & 18.3 & 0.8 & $16.8-21.7$ & 18.4 & 1.2 & $13.2-23.4$ & 18.4 & 2.2 \\
\hline Interorbital & $38.6-48.0$ & 43.2 & 3.3 & $38.8-48.0$ & 43.8 & 2.2 & $38.3-46.7$ & 42.6 & 2.2 & $40.2-48.4$ & 43.0 & 1.6 \\
\hline Head Depth & $61.4-72.6$ & 67.5 & 3.1 & $64.4-71.9$ & 67.8 & 2.2 & $61.0-73.7$ & 66.2 & 3.4 & $60.8-69.5$ & 65.3 & 2.3 \\
\hline Mouth Length & $56.6-69.6$ & 62.9 & 3.4 & $56.1-65.5$ & 59.7 & 2.6 & $55.4-66.9$ & 61.7 & 2.7 & $56.8-66.6$ & 61.5 & 2.7 \\
\hline Mouth Width & $68.5-82.4$ & 75.9 & 4.1 & $79.8-88.2$ & 85.1 & 2.7 & $70.8-85.4$ & 78.4 & 3.4 & $74.4-88.8$ & 80.6 & 4.0 \\
\hline Barbel Length & $4.6-10.7$ & 7.6 & 1.9 & $4.9-9.1$ & 6.7 & 1.0 & $5.4-8.8$ & 7.4 & 0.9 & $5.1-10.9$ & 8.4 & 1.4 \\
\hline Dent & $25.1-32.9$ & 29.1 & 2.1 & $27.5-32.4$ & 29.8 & 1.3 & $24.0-30.4$ & 27.0 & 1.4 & $27.2-36.3$ & 30.6 & 2.1 \\
\hline Premaxillary Tooth-cup Length & $22.6-28.0$ & 25.6 & 1.8 & $22.0-27.8$ & 25.6 & 1.5 & $20.3-26.6$ & 23.4 & 1.5 & $22.9-30.4$ & 26.3 & 2.1 \\
\hline
\end{tabular}




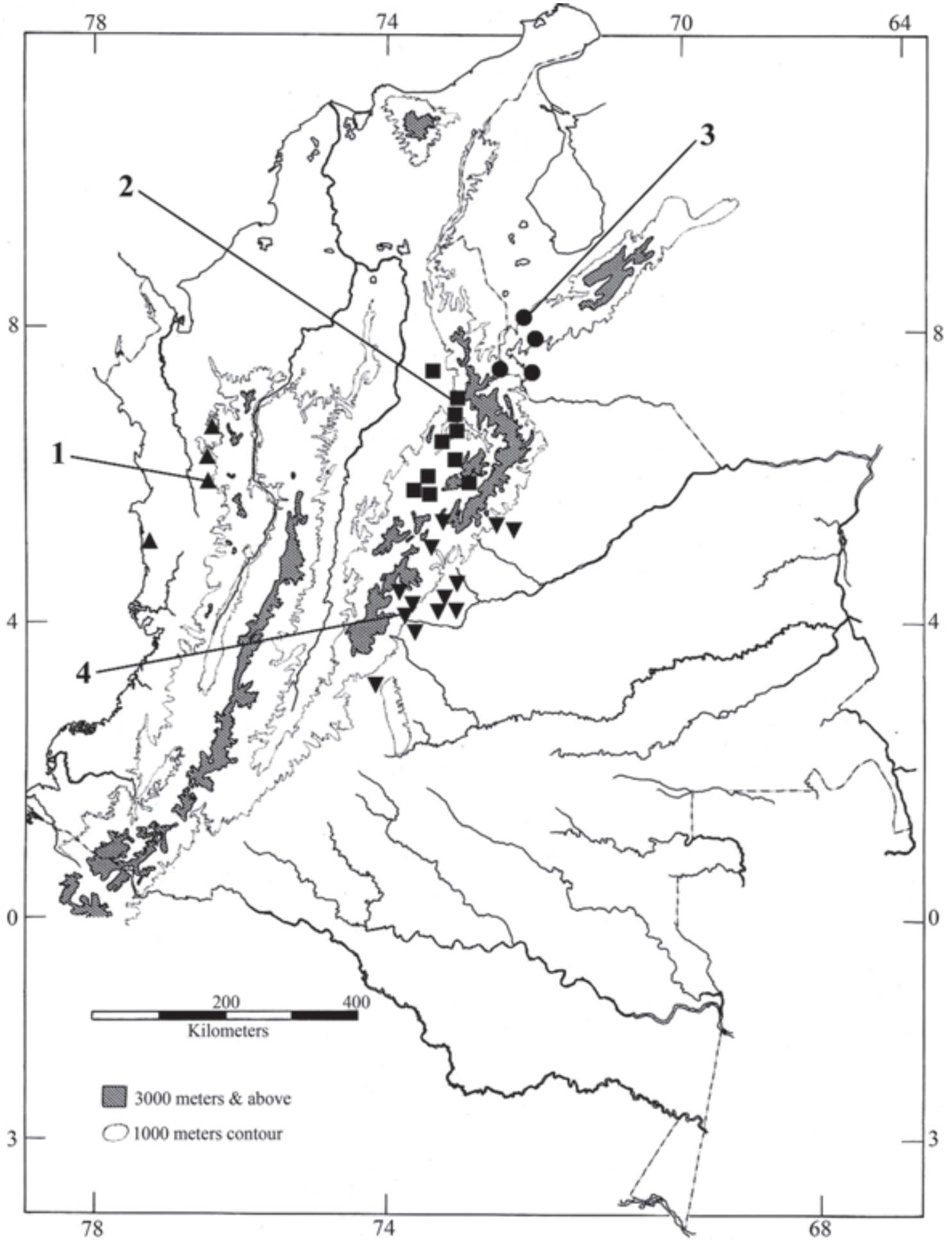

Fig. 2. Map of Colombia showing localities for the species of Dolichancistrus. Dotted contours represent 1000 masl isoclines and striped areas indicate regions above 3000 masl. Some symbols represent more than one locality and/or lot of specimens. Dolichancistrus atratoensis (triangles; type locality $=1$ ); $D$. carnegiei (squares; type locality $=2$ ); $D$. cobrensis (circles; type locality = 3); $D$. fuesslii (inverted triangles; type locality = 4). Base map provided by John D. Lynch. 
collected at Quibdó in the Departmento de Chocó on 5 and 14 August, at El Carmen de Atrato on August 8, and quebrada La Noche on 7-10 August. All these localities are distant from Riosucio, which is clearly an incorrect emendation. One of the two lots (IAvH-P 6629) cited as Dolichancistrus atratoensis by Maldonado-Ocampo et al. (2006) is instead a species of Leptoancistrus.

\section{Dolichancistrus carnegiei (Eigenmann, 1916) Fig. 3}

Pseudancistrus carnegiei Eigenmann, 1916: 85 [type locality: Colombia, Santander, río San Gil = río Fonce, see under Remarks]. - Eigenmann, 1922: 79, fig., 18, pl., 10, fig. 3 [Colombia, río Guaduas, río San Gil, quebrada de Honda, quebrada de la Pelada, río Baipé]. - Henn, 1928: 85 [type despository]. - Fowler, 1942: 132 [Colombia, río Magdalena and río Guaduas]. - Gosline, 1945: 90 [in checklist of Neotropical catfishes]. - Miles, 1947: 108 [Colombia, río Magdalena, Santander and Boyacá]. - Dahl, 1971: 85, fig. [Colombia, Santander and Boyacá in rivers and quebradas of Cordillera Oriental; maximum size; economic importance]. - Ibarra \& Stewart, 1987: 70 [type depository].

Lasiancistrus carnegiei Isbrücker, 1980: 43 [shift to Lasiancistrus].

Dolichancistrus carnegiei Isbrücker, 2001: 26 [shift to Dolichancistrus]. - Fisch-Muller, 2003: 384 [in checklist of species of the Ancistrinae]. - Maldonado-Ocampo et al., 2005: 153, map 144 [Andes of Colombia, río San Gil; summary data]. - Mojica et al., 2006: 33 [ Colombia, middle río Magdalena]. - Ferraris, 2007: 235 [in checklist of catfishes]. - Maldonado-Ocampo et al., 2008: 198 [in checklist of fishes of Colombia].

Material examined. All collections from Colombia. CAS 56749 (formerly IU 13926), 2, 89.0-126.4 mm SL, Departamento de Boyacá, río Baipe. CAS 77345 (formerly IU 13662), 4, paratypes, 14.7-23.4 mm SL, Departamento de Santander, Socorro, río Honda (= quebrada Honda). FMNH 58559 (formerly CM 7579a), 1, 24.4 mm SL, Departamento de Santander, quebrada La Pelada (location undetermined). IAvH-P 3936, 3, 38.6-123.7 mm SL, Departamento de Boyacá, río Magdalena drainage, without exact locality data. IAvH-P 3937, 1, 109.1 mm SL, Departamento de Boyacá, Villa de Leyva, río Suárez. IAvH-P 3938, 1, 44.8 mm SL, Departamento de Boyacá, Villa de Leyva, río Suárez. IAvH-P 4329, 2, 43.1-44.3 mm SL, Departamento de Santander, Floridablanca, río Lebrija, río Frío. IAvH-P 4330, 14, 29.3-49.7 mm SL, Departamento de Santander, Piedecuesta, río Chicamocha, río Manco. IAvH-P 4332, 25, 22.0$92.5 \mathrm{~mm}$ SL, Departamento de Santander, Piedecuesta, río Chicamocha, río Manco. IAvH-P 5263, 21, 31.6-152.6 mm SL, Departamento de Boyacá, Iguaque, río Iguaque, Pozo de La Vieja. IAvH-P 8563, 4, 37.6-104.8 mm SL, Departamento de Boyacá, Santa Sofía, río Moniquirá at Paso del Ángel. IAvH-P 10733, 6, 61.2-101.0 mm SL, Departamento de Boyacá, río Cane above Pozo de La Vieja. IAvH-P 10734, 33, 27.4-152.1 mm SL, Departamento de Boyacá, río Cane-Iguaque, valle Escondido. IAvH-P 11382, 2,
73.8 -93.0 mm SL, Departamento de Boyacá, río Magdalena drainage, without exact locality data. ICNMHN 591, 16, 35.5-96.3 mm SL, Departamento de Santander, Simacota, quebrada Santa Rosa, tributary of río Suárez. ICNMHN 1822, 2, 104.4-121.0 mm SL, Departamento de Boyacá, Togüí, finca Versalles, río Ubaza. ICNMHN 3235, 6, 36.9-68.1 mm SL, Departamento de Santander, Charalá, corregimiento de Virolín. ICNMHN 5371, 5, 48.0-84.8 mm SL, Departamento de Santander, Simacota-Chima road, quebrada Guamacá. ICNMHN 5445, 9, 47.7-117.0 mm SL, Departamento de Boyacá, río Suárez, río Sáchica. ICNMHN 15328, 1, 85.6 mm SL (female), Without exact locality data. ICNMHN 15329, 1, $85.9 \mathrm{~mm}$ SL (female), Without exact locality data. ICNMHN 15330, 1, 80.9 mm SL (female),Without exact locality data. ICNMHN 15331, 1, $77.9 \mathrm{~mm}$ SL (female), Without exact locality data. ICNMHN 15332, 1, $72.5 \mathrm{~mm}$ SL (female), Without exact locality data. ICNMHN 15333, 1, $89.9 \mathrm{~mm} \mathrm{SL}$ (female), Without exact locality data. ICNMHN 15334, 1, 103.6 mm SL (female), Without exact locality data. ICNMHN 15335, 1, $76.8 \mathrm{~mm}$ SL (female), Without exact locality data. ICNMHN 15336, 1, $81.9 \mathrm{~mm}$ SL (female), Without exact locality data. ICNMHN 16016, 7, 21.9-54.4 mm SL, Departamento de Santander, El Playón, río Lebrija, quebrada La Naranjera. ICNMHN 16017, 1, 42.8 mm SL, Departamento de Santander, El Playón, río Lebrija, quebrada La Naranjera. ICNMHN 16018, 3, 22.8-46.5 mm SL, Departamento de Santander, El Playón, río Lebrija, quebrada La Naranjera. ICNMHN 17498, 3, 48.6-106.8 mm SL, Departamento de Boyacá, río Suárez, río Sáchica. ICNMHN 17500, 6, 76.2-127.4 mm SL, Without exact locality data. ICNMHN 17501, 42, 59.36-120.58 mm SL, 4 cs, Departamento de Santander, Bucaramanga, río Tona. ICNMHN 17505, 3, formerly CAR 102, 76.7-61.2 mm SL, Departamento de Santander, Floridablanca, río Lebrija, río Frío. MLS 522, 11, (43.6-129.4 mm SL), Departamento de Boyacá, Santa Rosa de Viterbo, río Arriba. MLS 542, 1, 120.2 mm SL, Departamento de Boyacá, Santa Rosa de Viterbo, río Arriba. MLS 543, 6, 61.9-89.4 mm SL, Departamento de Santander, San Gil. MLS 550, 1, 63.5 mm SL, Departamento de Santander, San Gil.

Diagnosis. Dolichancistrus carnegiei can be separated from all congeners in the size and form of the cheek plates (plates externally of approximately the same size and nearly square from lateral view with the anterior margin of posterior cheek plate not reaching to the anterior margin of exposed opercle vs. the anterior plate longitudinally shorter than the posterior plate in $D$. atratoensis or both plates about the same size but rectangular in $D$. cobrensis and $D$. fuesslii). Dolichancistrus carnegiei is further distinguished from $D$. atratoensis in the length of the adpressed pectoral-fin spine in mature males (extending to the tip of the adpressed pelvic fin vs. extending only midway down the length of the adpressed pelvic fin, respectively) and in the distance from the base of the anal-fin spine to the tip of the fin (at least one-half vs. at most one-third of the length of the pelvic-fin spine, respectively). Dolichancistrus carnegiei additionally differs from $D$. cobrensis in the condition of the buccal papilla within the oral cavity at the limit of the symphysis of the premaxillae (present vs. absent, respectively) and the pattern of development of the enlarged odontodes along the margin of the snout in mature males (odontodes present along the entire anterior and anterolateral margins of the snout vs. limited to the lateral margins of the snout, respectively). Dolichancistrus carnegiei is further 
distinguished from $D$. fuesslii in the form of the distal margin of the pelvic fin in mature males (smoothly convex $v s$. W-shaped, respectively).

Description. See description under generic account for features general for Dolichancistrus. Largest examined specimen $153.7 \mathrm{~mm}$ SL. Morphometrics presented in Table
1. Dorsal-fin rays ii,8 or 9; anal-fin rays ii,2 or 3; caudal-fin rays i,14,i; pectoral-fin rays i,6; pelvic-fin rays i,5. Preadipose plates 2 or 3; median plates 24 to 26 . Buccal papilla present within oral cavity at limit of symphysis of premaxillae. Enlarged odontodes present along entire anterior and anterolateral margins of snout in mature males. Odontodes along lateral margin of snout terminate distinctly short of
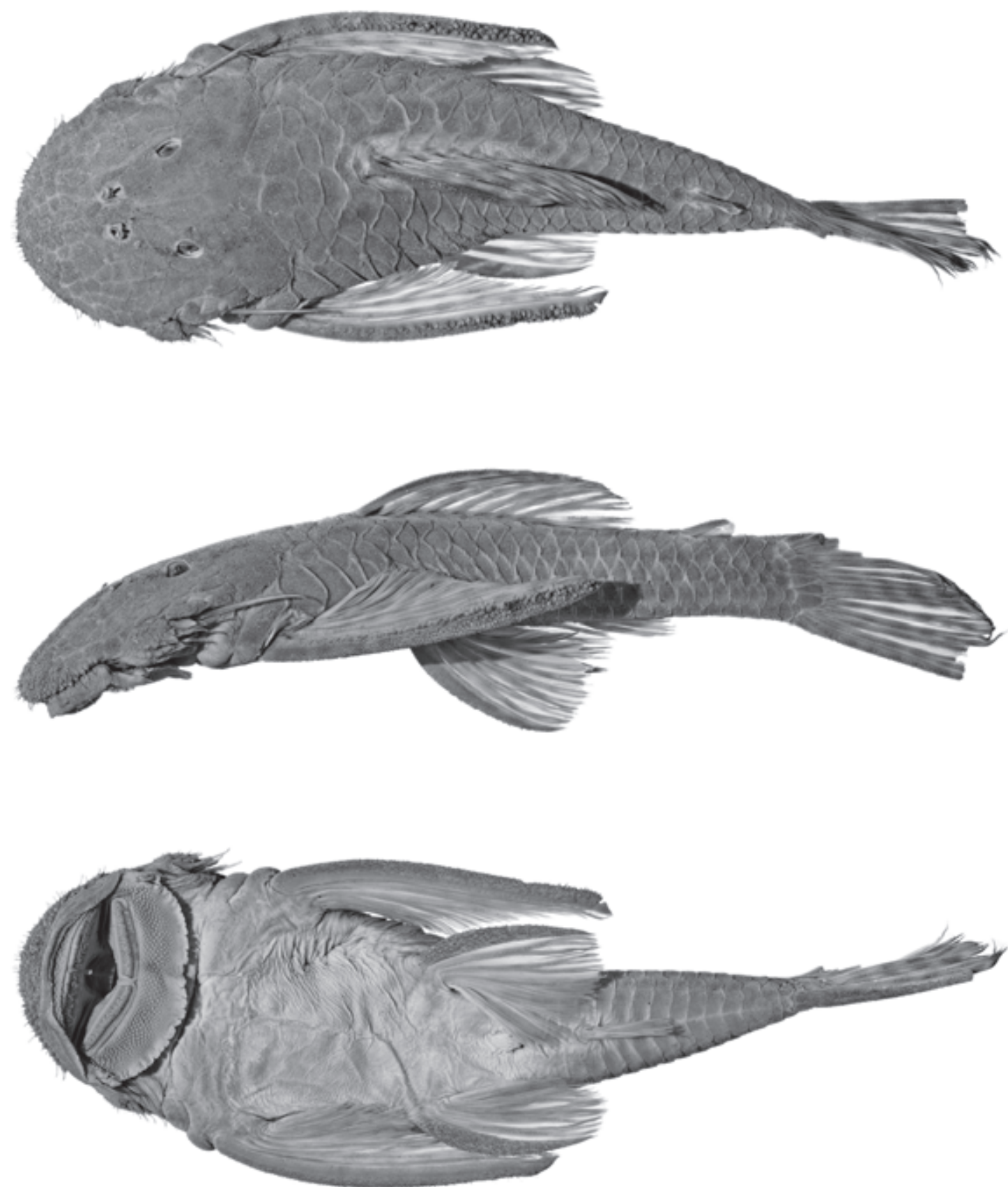

Fig. 3. Dolichancistrus carnegiei, CAS 56749, 126.4 mm SL. Colombia, Departamento de Boyacá, río Baipé: dorsal, lateral and ventral views. 
anterior margin of cheek plates. Anterior margin of posterior cheek plate distinctly separated from anterior margin of exposed portion of opercle. Anterior and posterior cheek plates of approximately same length; square in lateral view. Hypertrophied cheek odontodes recurved distally. Distal margin of pelvic fin straight in juveniles and smoothly convex in mature specimens. Adpressed pectoral-fin spine reaching posteriorly to area between middle and tip of adpressed pelvic fin in mature males and to middle of pelvicfin spine in mature females. Odontodes extending over distal one-third of dorsal surface of pectoral-fin spine. Caudal-fin margin oblique to slightly emarginate.

Coloration in alcohol. Overall ground coloration of head and body brownish on lateral and dorsal surfaces, lightly pigmented ventrally other than for brown upper lip. Longitudinal dark lateral stripe evident in juveniles and sometimes in adults. Dorsolateral region of body in juveniles with some more lightly colored patches, particularly in area underneath dorsal fin but with clear patches barely evident in some adults. Largest examined individual with nearly uniform dark coloration on head and body. Dorsal fin with alternating dark and light areas along rays; pigmentation forms irregular oblique stripe-like pattern along length of fin. Spacing between dark marks on rays variable, but individual dark areas always distinct. Dorsal-fin membranes typically unpigmented, but pigmentation patches overlying rays extend onto adjacent membranes in some individuals. Anal fin with dark pigmentation in form of transverse bands or single diffuse spot. Caudal fin with alternating dark and light areas along rays; pigmentation forms irregular transverse bar-like pattern across vertical extent of fin. Pectoral-fin spine with alternating dark and light stripes along dorsal surface and ventral surface unpigmented. Largest examined specimen with dorsal surface of spine nearly uniformly dark. Pectoralfin rays with alternating dark and light areas forming stripelike transverse pattern. Pelvic-fin spine with alternating dark and light areas along dorsal surface; pattern more obvious in larger individuals. Pelvic-fin rays with some irregular darker areas on rays in smaller individuals, but with diffuse barring pattern in larger specimens.

Sexual dimorphism. Mature males of Dolichancistrus carnegiei have odontodes along the margin of the snout very slightly more developed than in mature females or dimorphism in this feature is absent. Mature males have proportionally longer pectoral-fin spines than mature females.

Distribution. Dolichancistrus carnegiei occurs in eastern tributaries of the middle portion of the río Magdalena basin along the Cordillera Oriental in the departments of Boyacá and Santander, Colombia (Fig. 2).

Remarks. Eigenmann (1916) reported the type locality for Dolichancistrus carnegiei as the río San Gil; however, the official name for this river in the municipality of San
Gil, Santander was changed to río Fonce early in the twentieth century (R. Caicedo, pers. comm.). Dahl (1971: 85) reported that Dolichancistrus carnegiei (his Pseudancistrus carnegiei) grows to approximately $20 \mathrm{~cm}$ (SL?). Both Miles (1947: 108) and Dahl (1971: 85) noted that the species was exploited for food and was of some economic importance.

Specimens of Dolichancistrus carnegiei from Boyacá, Colombia (IAvH-P 5263, 10733, 10735) vary in the degree of fin development and some individuals have foreshortened pectoral, pelvic, caudal, and anal fins albeit without any obvious pattern to these reductions. These individuals also differ in the pigmentation of the lateral surface of the body, most prominently in the presence of unpigmented regions. This variation likely represents populational anomalies. Samples with definitive locality data show $D$. carnegiei and $D$. fuesslii to be allopatrically distributed; however, these species are commingled a few ICNMHN and IAvH-P lots. These series were collected along potential trans-cordilleran oil pipeline routes spanning the distribution of the two species and likely represent intermingled samples collected to both sides of the Cordillera Oriental.

\section{Dolichancistrus cobrensis (Schultz, 1944) Fig. 4}

Pseudancistrus pediculatus cobrensis Schultz, 1944: 299, pl. 9, fig. b [type locality: Venezuela, Maracaibo basin, río Catatumbo basin, río Cobre, tributary to río Quinta, latter tributary to río La Grita, below La Grita]. - Gosline, 1945: 90 [in checklist of Neotropical catfishes]. - Mago-Leccia, 1970: 26 [Venezuela; common name]. - Nijssen et al., 1982: 61 [type depository]. - Ferraris \& Vari, 1992: 31 [type depository]. - Provenzano et al., 1998: 212 [type depository]. - Galvis et al., 1997: 96 [Colombia, Lago Maracaibo basin, río Catatumbo; illustrated specimen misidentified].

Dolichancistrus cobrensis Isbrücker, 1980: 48 [shift to Dolichancistrus]. - Burgess, 1989: 434 [in listing of species of Loricariidae]. - Taphorn et al., 1997: 87 [Venezuela]. - Isbrücker, 2001: 26 [in listing of species of Loricariidae]. - Isbrücker, 2002: 15 [in listing of species of Loricariidae]. - Fisch-Muller, 2003: 384 [in checklist of species of the Ancistrinae]. - Armbruster, 2004a: 48, fig. 38 [in phylogenetic analysis of Loricariidae]. - Lasso et al., 2004a: 173 [Lago Maracaibo basin]. - Ferraris, 2007: 235 [in checklist of catfishes].

Material examined. AUM 46306, 22, 4, 56.1-92.0 mm SL, Venezuela, río Orinoco drainage, río San Antonio, tributary of río San Jose de Bolivar-río Uribante system. AUM 30377, 12, 2, 73.7-76.0 mm SL, 3 cs, Venezuela, río Orinoco drainage, río San Antonio, tributary of río San Jose de Bolivar-río Uribante system. MCNG 541, 2, 30.9-54.1 mm SL, Colombia, Departamento de Norte de Santander, El Guayabal, Cúcuta-Chinácota road. 
MCNG 6470, 4, 36.0-55.0 mm SL, Venezuela, río Orinoco drainage, río Quirimari basin, quebrada La Legia, along river above Alquitrona at bridge to Liberta, 7³8'28”N 72²2'30”W. USNM 121036, holotype, 78.0 mm SL, Venezuela, Estado de Táchira, Lago Maracaibo basin, río Cobre, tributary to río Quinta, latter tributary to río La Grita, below La Grita. USNM 121037, paratypes, $4000+(20,10$ males and 10 females, 47.6-63.1 mm SL), Venezuela, Estado de Táchira, Lago Maracaibo basin, río Cobre, tributary to río Quinta, latter tributary to río La Grita, below La Grita.
Diagnosis. Dolichancistrus cobrensis is distinguished from all congeners in the condition of the buccal papilla at the limit of the symphysis of the premaxillae (papilla absent vs. present, respectively). Dolichancistrus cobrensis further differs from $D$. atratoensis in the length of the pectoral-fin spine in mature males (extending beyond the tip of the adpressed pelvic fin vs. extending only midway down the length of the adpressed pelvic fin, respectively). Dolichancistrus cobrensis is additionally distinguished
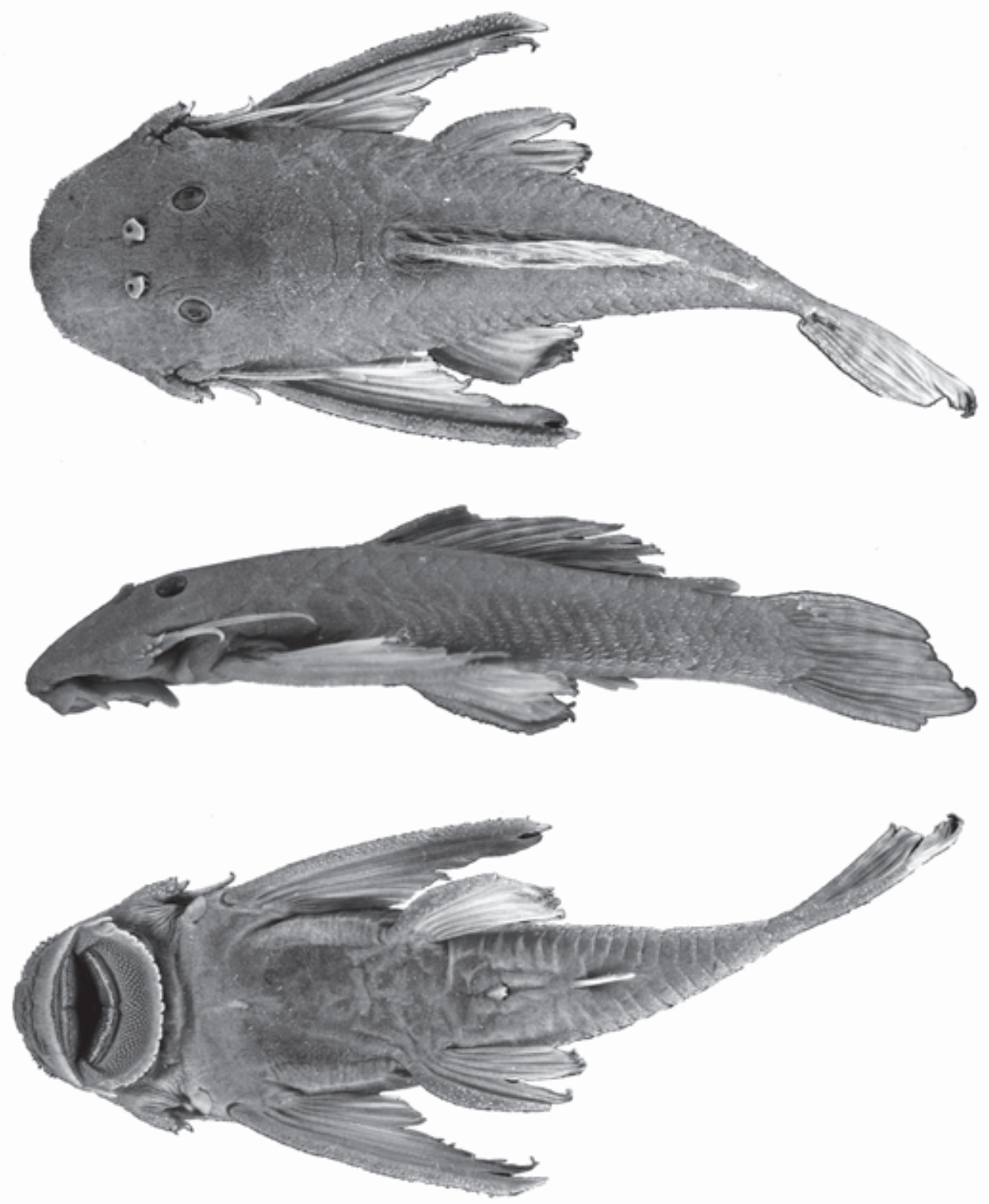

Fig. 4. Dolichancistrus cobrensis, MCNG 541, 54.1mm SL. Colombia, Departamento de Norte de Santander, El Guayabal, Cúcuta - Chinácota road; dorsal, lateral and ventral views. 
from $D$. carnegiei in the pattern of development of the enlarged odontodes along the margin of the snout in mature males (odontodes limited to the lateral margins of the snout $v s$. extending along the entire anterior and anterolateral margins of the snout, respectively). Dolichancistrus cobrensis further differs from $D$. fuesslii in the form of the distal margin of the pelvic fin in males (approximately smoothly convex vs. W-shaped, respectively), the pattern of distribution of the odontodes along the margin of the snout (odontodes located primarily along the lateral margin of the snout vs. extending along the entire anterior and anterolateral margins of the snout, respectively), and the extent of development of the odontodes on the dorsal portion of the pectoral-fin spine (extending over distal onethird of the spine vs. over distal one-half of the spine, respectively).

Description. See description under generic account for features general for Dolichancistrus. Largest examined specimen $92.0 \mathrm{~mm}$ SL. Morphometrics presented in Table 1. Dorsal-fin rays ii,7 to 9; anal-fin rays ii,3; caudal-fin rays $i, 14, i$; pectoral-fin rays $i, 6$; pelvic-fin rays $i, 5$. Preadipose plates 2 or 3; median plates 24 or 25 . Buccal papilla within oral cavity absent at limit of symphysis of premaxillae. Enlarged odontodes in mature specimens present along anterolateral margins of snout but absent from anterior margin of snout. Odontodes along lateral margin of snout terminate distinctly short of anterior margin of cheek plates and not showing sexual dimorphism contrary to presence of dimorphism in other species of Dolichancistrus. Anterior margin of posterior cheek plate slightly separated from exposed portion of opercle. Anterior and posterior cheek plates square, of approximately same length. Hypertrophied odontodes on cheek apparatus recurved distally. Distal margin of pelvic fin smoothly convex. Adpressed pectoral-fin spine in mature males reaching posteriorly distinctly beyond tip of adpressed pelvic fin. Adpressed pectoral-fin spine of mature females reaching posteriorly to within area slightly beyond midpoint of adpressed pelvic fin and slightly short of tip of pelvic fin. Odontodes extending over nearly distal one-third of dorsal portion of pectoral-fin spine.

Coloration in alcohol. Overall ground coloration of head and body brownish on lateral and dorsal surfaces, lightly colored ventrally other than for brown upper lip. Head with patch of somewhat darker pigmentation in region anterior and ventral to orbit. Body in juveniles and smaller individuals with five distinct midlateral dark spots; anteriormost spot located slightly anterior to vertical through dorsal-fin origin and posteriormost spot on caudal peduncle. Midlateral series of dark spots of larger individual variably coalesce to give appearance of irregular midlateral stripe in some individuals. Dorsal surface of body with four saddle-like marks more obvious in smaller individuals. First mark located under anterior portion of dorsal fin, second under base of posterior dorsal-fin rays, third between dorsal and adipose fins, and fourth immediately behind posterior terminus of adipose fin. Contralateral third and fourth marks continuous across dorsal midline. Dorsal fin with alternating dark and light areas along rays that form irregular stripe-like pattern along length of fin. Dorsalfin membranes lack dark pigmentation. Anal fin lacking dark pigmentation. Caudal fin with alternating dark and light areas on rays that form irregular transverse bar-like pattern across vertical extent of fin. Pectoral-fin spine with alternating dark and light regions on dorsal surface and with ventral surface lacking dark pigmentation. Pectoralfin rays in smaller individuals without obvious dark pigmentation; larger specimens with alternating dark and light pigment pattern on lateral rays, but with medial rays and all membranes lacking dark pigmentation. Pelvic-fin spine with alternating dark and light areas; pattern more obvious in larger individuals. Pelvic-fin rays with some irregular darker areas on rays, but without distinct barring pattern. Pigmentation less obvious in smaller individuals.

Sexual dimorphism. Mature males and females of Dolichancistrus cobrensis have comparably developed odontodes along the lateral margins of the snout, contrary to the distinctly larger odontodes in males versus females in congeners. The pectoral-fin spines of mature males are proportionally longer than those of mature females.

Distribution. Dolichancistrus cobrensis is known from the southern portion of the río Catatumbo, a western tributary to Lago Maracaibo basin in Colombia and Venezuela, and localities in the upper río Apure in the río Orinoco basin (Fig. 2).

Common name. Chorrosco, panche (Mago-Leccia, 1970: 86).

Habitat. Schultz (1944: 299) reported that the types of the species were collected in "very swiftly running water among rubble to gravel.”

Remarks. In the description of Dolichancistrus cobrensis, Schultz (1944: 299) recognized it as a subspecies of Pseudancistrus pediculatus and differentiated his $P$. pediculatus cobrensis from $P$. pediculatus pediculatus (= Dolichancistrus fuesslii herein) by color pattern and minor mean meristic differences. Isbrücker (1980: 48) recognized Pseudancistrus pediculatus cobrensis as a species, Dolichancistrus cobrensis, without discussion of the basis for the transition to species status. Subsequent authors followed Isbrücker (1980). Our analysis revealed that $P$. pediculatus cobrensis and $P$. pediculatus pediculatus (= Dolichancistrus fuesslii) differ in the form of the pelvic-fin margin, the relationship of the posterior cheek plate with the exposed portion of the opercle, the condition of the buccal papilla at the posterior limit of the premaxillary symphysis, the pattern of distribution of odontodes along the snout margin, and the development of odontodes along the dorsal 
portion of the pectoral fin. These forms are considered distinct, but with $P$. pediculatus pediculatus as a synonym of Dolichancistrus fuesslii (see Remarks under D. fuesslii).

Galvis et al. (1997: 96) included a life coloration photo in their account of Pseudancistrus pediculatus cobrensis (the Dolichancistrus cobrensis of this study) from the río Catatumbo in Colombia. The illustrated specimen is rather an individual of Lasiancistrus, most likely L. guacharote which is the only member of the genus reported from that basin.

\section{Dolichancistrus fuesslii (Steindachner, 1911)}

Fig. 5

Ancistrus füsslii Steindachner, 1911: 373 [type locality: Ostkolumbien, Sosomoco, $800 \mathrm{~m}$ Höhe (= Eastern Colombia, Sosomoco, 800 m elevation; see under Remarks concerning type locality information)].

Pseudancistrus pediculatus Eigenmann, 1917: 679 [type locality: Colombia, río Negro Villavicencio]. -
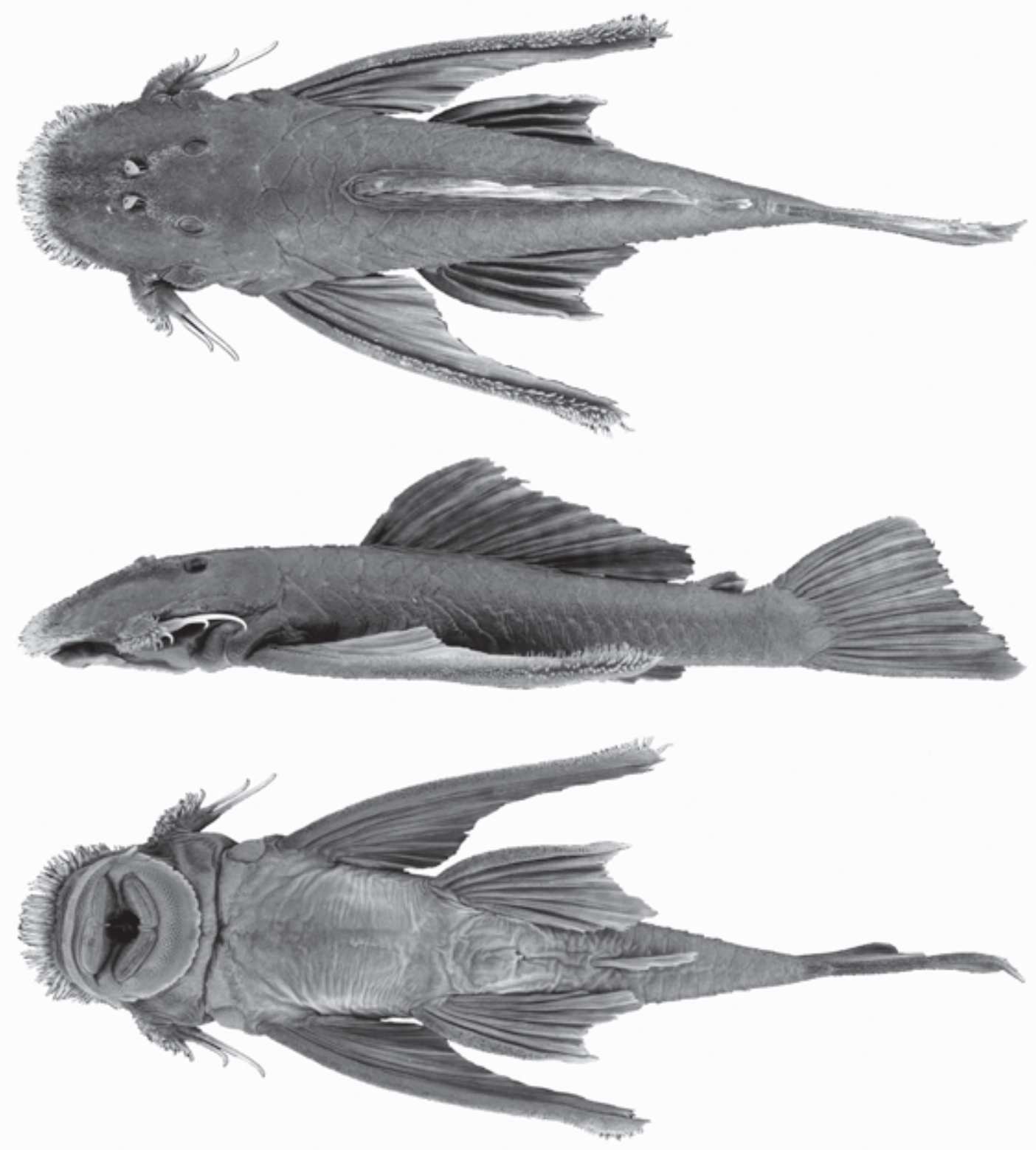

Fig. 5. Dolichancistrus fuesslii, ICNMHN 14582, 117 mm SL. Colombia, Departamento de Boyacá, río Garagoa basin; dorsal, lateral and ventral views. 
Eigenmann, 1922: 78, 224; fig. 17, pl. 10, fig. 4, pl. 12, fig. 3 [in part, Colombia, Villavicencio, Barrigón, Tengavita; record from río San Juan basin of western Colombia questionable, see Remarks]. - Henn, 1928: 85 [type depository]. - Fowler, 1942: 132 [Colombia, río Meta; not citations of species from río San Juan and río Tamana]. - Gosline, 1945: 90 [in checklist]. - Ibarra \& Stewart, 1987: 70 [type depository].

Lasiancistrus fuesslii Isbrücker, 1980: 44 [correction of diacritic mark in specific epithet; shift to Lasiancistrus].

Dolichancistrus pediculatus Isbrücker, 1980: 48 [shift to Dolichancistrus]. - Isbrücker, 2001: 27 [in listing of species of the Loricariidae]. - Isbrücker, 2002: 27 [in listing of species of the Loricariidae]. - Burgess, 1989: 434 [in listing of species of Loricariidae]. - Fisch-Muller, 2003: 384 [in checklist of species of Ancistrinae]. - Lasso et al. 2004a: 173 [río Orinoco basin]. - Armbruster, 2004a: 48, fig. 38 [phylogenetic systematics of Loricariidae]. Lasso et al., 2004b: 131 [río Meta basin]. - MaldonadoOcampo et al., 2005: 154, map 146 [in part; Andes of Colombia, río Negro at Villavicencio; summary data]. Ferraris, 2007: 235 [in checklist of catfishes]. Maldonado-Ocampo et al., 2008: 198 [Colombia]. Urbano-Bonilla et al., 2009: 160 [Colombia, Departamento de Casanare].

Dolichancistrus fuesslii Isbrücker, 2001: 27 [shift to Dolichancistrus]. - Isbrücker, 2002: 27 [in listing of species of the Loricariidae]. - Fisch-Muller, 2003: 384 [in checklist of species of Ancistrinae]. - MaldonadoOcampo et al., 2005: 154, map 146 [Andes of Colombia; Sosomoco (= Meta, Quebrada Susumuco; correction of misspelling and elaboration of originally cited type locality; see Remarks); summary data and translation of original description of A. fuesslii Steindachner]. Ferraris, 2007: 235 [in checklist of catfishes]. Maldonado-Ocampo, 2008: 198 [Colombia].

Material examined. All collections from Colombia. CAS 58789 (formerly IU 13928), paratypes of Pseudancistrus pediculatus, 7 , 5, 47.94-80.95 mm SL, Departamento de Meta, Villavicencio, quebrada Gramalote. CAS 58790 (formerly IU 13665), 3, 2, 32.9$38.3 \mathrm{~mm}$ SL, Departamento de Meta, Villavicencio, quebrada Gramalote. CAS 58795 (formerly IU 13945), 6, 19.1-32.7 mm SL, Departamento de Meta, Villavicencio, quebrada Sumico (= Susumuco). CAS 58799 (formerly IU 13939), 5, 12.7-43.5 mm SL, Departamento de Cundinamarca, Quetame, río Contador. CAS 58820 (formerly IU 13929), paratypes of Pseudancistrus pediculatus, 2, 59.7-72.1 mm SL, Departamento de Meta, Puerto Porfía, Barrigona. CZUT-IC 3327, 1, 63.5 mm SL, Departamento de Boyacá, San Luis de Gaceno, vereda Calichama, quebrada El Chopal, tributary of río Lengupa. CZUT-IC 3346, 1, 47.3 mm SL, Sabanalarga, Vereda San Joaquín, quebrada La Raya, tributary of río Upía. CZUT-IC 5491, 13, 21.6-63.9 mm SL, Departamento de Casanare, quebrada Agua Blanca. FMNH 40217, 1, 95.3 mm SL, Departamento de Meta, Villavicencio. FMNH 58562, 6, 12.8-22.7 mm SL, Departamento de Cundinamarca, Quetame, río Contador. FMNH 58563, 21, 13.4-43.2 mm SL, Departamento de Meta, Villavicencio, quebrada Blanca. FMNH 58566, 17, 2 cs, 22.5-67.4 mm SL, Departamento de Meta, Villavicencio. IAvH-P 3939, 7, 42.2-85.3 mm SL, Departamento de Boyacá, río Jenesano. IAvH-P 3940, 16, 40.6-103.1 mm SL, Departamento de Boyacá, río Orinoco drainage, río Meta basin, without exact locality data. IAvH-P 7931, 22, 16.8-33.3 mm SL, Departamento de Meta, Villavicencio, Quebrada Susumuco, at mouth into río Negro. IAvH-P 9230, 22, 58.6-97.0 mm SL, Departamento de Casanare, Aguazul, AguazulSogamoso road, quebrada Chichaca IAvH-P 9605, 7, 63.5-124.4 mm SL, Departamento de Casanare, Aguazul, Aguazul-Sogamoso road, quebrada Chichaca. IAvH-P 11381, 9, 25.8-105.8 mm SL, Departamento de Boyacá, río Orinoco drainage, río Meta basin, without exact locality data. ICNMHN 1177, 1, 97.9 mm SL, Departamento de Meta, Acacías, Acacías-Guamal road, unnamed tributary of río Acacías. ICNMHN 1196, 2, 57.9-85.5 mm SL, Departamento de Meta, Acacías, río Acacías, río Playón, 500 masl. ICNMHN 1474, 14, 33.0 - 80.3 mm SL, Departamento de Cundinamarca, Cáqueza, río Negro, río Cáqueza. ICNMHN 1475, 10, 29.8-62.5 mm SL, Departamento de Cundinamarca, Cáqueza, río Saname. ICNMHN 2638, 11, 35.7-95.1 mm SL, Departamento de Casanare, Aguazul, quebrada Costa Grande near retén de Guadalcanal, 860 masl. ICNMHN 2650, 5, 62.4-96.5 mm SL, Departamento de Casanare, Aguazul, quebrada Costa Grande, 860 masl. ICNMHN 2817, 7, 60.8-93.3 mm SL, Yopal, quebrada Costa Grande, near Pajarito (Boyacá), 800 masl. ICNMHN 2839, 1, 66.0 mm SL, Departamento de Boyacá, San Luis de Gaceno, quebrada La Quinchalera. ICNMHN 3212, 12, 22.3-80.9 mm SL, Departamento de Boyacá, Santa María, río Batá, road to Chivor. ICNMHN 3385, 1, 62.6 mm SL, Departamento de Meta, Guamal, caño Camelia. ICNMHN 3560, 2, 37.0-49.3 mm SL, Departamento de Meta, Serranía de La Macarena, río Duda, río Guape between Cruce Oriente and quebrada Uribe. ICNMHN 3641, 6, 45.2-64.8 mm SL, Departamento de Meta, Acacías, río Acacías, caño Acacías. ICNMHN 7945, 26, 22.7-90.0 mm SL, Departamento de Boyacá, Pajarito, río Cusiana. ICNMHN 7979, 2, 40.0-69.2 mm SL, Colombia, no specific locality data. ICNMHN 7993, 3, 33.7-62.9 mm SL, ICNMHN catalog data citing collection locality as near Leticia incorrect; see Ballen (2011) for further details. ICNMHN 7996, 12, 32.6-72.7 mm SL, Colombia, no specific locality data. ICNMHN 8003, 1, 56.1 mm SL, Departamento de Meta, Cumaral, caño Pecuca, quebrada Piedras Negras. ICNMHN 13198, 1, 53.6 mm SL, Departamento de Meta, Cumaral, río Guacavia, caño Pecuca. ICNMHN 14582, 30, 56.5-117.0 mm SL, Departamento de Boyacá, Santa María, río Garagoa basin. ICNMHN 15337, 1, 62.3 mm SL, female, Colombia, no specific locality data. ICNMHN 15338, 1, $74.7 \mathrm{~mm}$ SL, female, Colombia, no specific locality data. ICNMHN 15339, 1, 81.6 mm SL, female, Colombia, no specific locality data. ICNMHN 15340, 1, $84.1 \mathrm{~mm}$ SL, male, Colombia, no specific locality data. ICNMHN 16811, 4, 85.2-101.8 mm SL, Departamento de Boyacá, Jenesano, río Garagoa, 2100 masl. ICNMHN 17504 (formerly CAR 294), 1, 68.9 mm SL, Departamento de Boyacá, río Jenesano. MLS 538, 1, 102.9 mm SL, Departamento de Boyacá, Guaicaramo. MLS 545, 2, 85.8-100.7 mm SL, Colombia, no specific locality data. MLS 549, 1, 76.4 mm SL, Departamento de Meta, Villavicencio. MLS 746, 4, 19.2-93.8 mm SL, Monterralo, YopalSogamoso road $15 \mathrm{~km}$ before Pajarito, quebrada Mesiana, tributary of quebrada Guacharaca. MLS 796, 1, 54.7 mm SL, Departamento de Cundinamarca, Tibirita, río Machetá, 1500 masl. NMW 48026, 1 (97.7 mm SL; holotype of Ancistrus fuesslii), Colombia: Ostkolumbien, Sosomoco, 800 m Höhe” (= eastern Colombia, Sosomoco, $800 \mathrm{~m}$ in elevation; see comments under Remarks concerning type locality). NRM 15171, 1, $47.9 \mathrm{~mm} \mathrm{SL}$, Departamento de Meta, Villavicencio, Buenavista, unnamed 
tributary of río Negro, NRM 30168, 1, 60.3 mm SL, Departamento de Cundinamarca, Quetame, río Contador. USNM 100786, 1, 78.9 mm SL, Departamento de Boyacá, Guaicaramo. NMW 48026, 1 (97.7 mm SL; holotype of Ancistrus fuesslii), Colombia: Ostkolumbien, Sosomoco, 800 m Höhe” (= eastern Colombia, Sosomoco, $800 \mathrm{~m}$ in elevation; see comments under Remarks concerning type locality).

Diagnosis. Dolichancistrus fuesslii is distinguished from all congeners in the form of the distal margin of the pelvic fin in mature males (margin of the fin distinctly W-shaped, with the longer lateralmost unbranched ray followed by a second ray that is distinctly shorter laterally and with the medial portion of the second ray and the third ray progressively longer than the first ray and followed by the progressively shorter fourth and fifth rays $v$ s. the margin of the pelvic fin straight to approximately smoothly convex, respectively). Dolichancistrus fuesslii is further separable from congeners in the relative position of the anteromedial margin of the posterior cheek plate with respect to the anterior margin of the exposed portion of opercle (anterior margin of posterior check plate in contact with anterior margin of the exposed portion of opercle when cheek apparatus adpressed $v s$. posterior cheek plate distinctly separated from anterior margin of exposed opercle). Dolichancistrus fuesslii can be further differentiated from $D$. atratoensis in the relative size and shape of the cheek plates (the two plates of approximately the same length and rectangular in shape, $v s$. the anterior plate approximately one-half the length of the posterior plate and triangular, respectively), the relative length of the pectoralfin spine in mature males (spine reaching posteriorly far beyond the posterior tip of the adpressed pelvic fin vs. only reaching midway along the length of the pelvic fin, respectively). Dolichancistrus fuesslii can be further separated from $D$. carnegiei in the relative shape of the cheek plates (both cheek plates rectangular, vs. square, respectively) and coloration pattern (presence of lateral dark blotches vs. diffuse marbling on lateral portions of body, respectively). Dolichancistrus fuesslii further differs from $D$. cobrensis in the condition of the buccal papilla within the oral cavity at the posterior limit of the premaxillary symphysis (a papilla present vs. absent, respectively) and the pattern of distribution of the hypertrophied odontodes along the margin of the snout in mature males (odontodes extensive and continuously distributed along the entire anterior and anterolateral margins of the snout, vs. odontodes restricted to the anterolateral corners of snout, respectively).

Description. See description under generic account for features common to all species of Dolichancistrus. Largest examined specimen $124.4 \mathrm{~mm}$ SL. Morphometrics and meristics presented in Table 1. Dorsal-fin rays ii,7 to 9; analfin rays ii,2 or 3; caudal-fin rays i,14,i [i,12,i in one aberrant individual]; pectoral-fin rays i,6; pelvic-fin rays i,5. Preadipose plates 2 or 3; median plates 24 or 25 . Buccal papilla present within oral cavity at symphysis of premaxillae. Enlarged odontodes present along entire anterolateral and anterior margins of snout and on median region of snout anterior to nares. Odontodes along snout margin terminate posteriorly distinctly short of anterior margin of cheek plates. Anterior margin of posterior cheek plate in contact with anterior exposed margin of opercle. Anterior and posterior cheek plates rectangular and approximately of same size. Hypertrophied cheek odontodes distally recurved. Distal margin of pelvic fin in mature males $\mathrm{W}$-shaped with longer first ray followed by shorter lateral branch of second ray and then increasingly longer medial branch of second ray and all of third ray and then progressively shorter fourth and fifth rays. Spine of adpressed pectoral fin of mature males surpassing tip of adpressed pelvic-fin spine. Adpressed pectoral-fin spine of mature females reaching posteriorly to within area from mid-length of adpressed pelvic fin to the tip of pelvic fin. Odontodes on dorsal surface of pectoral-fin spine extending over distal one-half of spine in mature males.

Coloration in alcohol. Overall ground coloration of head and body brownish on lateral and dorsal surfaces, lightly colored ventrally other than for brown upper lip. Body in juveniles and smaller individuals with five or six distinct midlateral dark spots ranging from slightly anterior of vertical through dorsal-fin origin to caudal peduncle. Midlateral series of dark spots less obvious in larger individuals. Some overall darker individuals with midlateral pigmentation barely apparent. Specimens collected from higher elevation locations sometimes lack discrete marks along sides of body, showing instead diffuse longitudinal stripe in that region. Dorsal surface of body with four saddle-like marks; marks more obvious in smaller individuals. First mark located under anterior portion of dorsal fin, second under base of posterior dorsal-fin rays, third between dorsal and adipose fins, and fourth immediately behind posterior terminus of adipose fin. Third and fourth marks continuous across dorsal midline. Saddlelike marks obscured in specimens with dark gray overall coloration. Dorsal fin with alternating variably separated dark and light areas along rays that form irregular bar-like pattern along length of fin. Dorsal-fin membranes lack dark pigmentation. Anal fin in most examined specimens lacks dark pigmentation, but some barring or spots present in samples from higher elevations. Caudal fin with alternating dark and light areas along rays that form irregular transverse bar-like pattern across vertical extent of fin. Pectoral-fin spine with alternating dark and light regions on dorsal surface but dark pigmentation absent from ventral surface. Pectoral-fin rays in smaller individuals without dark pigmentation; larger specimens with alternating dark and light pigment pattern on lateral rays, but with medial rays unpigmented. Pelvic-fin spine with alternating dark and light areas along length; pattern more obvious in larger individuals. Pelvic-fin rays with some irregular darker areas but distinct barring pattern on rays in smaller individuals and distinct barring in larger specimens. 
Sexual dimorphism. The pelvic-fin margin in Dolichancistrus fuesslii is sexually dimorphic, being distinctly $\mathrm{W}$-shaped in mature males versus broadly convex in mature females and immatures. Odontodes along the snout margin are more highly developed in mature males than in mature females.

Distribution. Dolichancistrus fuesslii occurs from the northern portion of the Serranía de La Macarena, Departamento do Meta north to Yopal, Departamento do Casanare, Colombia, at approximately 450 to 2100 masl. All records are from upland tributaries in the río Duda and río Meta basins along the eastern flank of the Cordillera Oriental in the río Orinoco system (Fig. 2). Samples of the species in ICNMHN supposedly from Leticia, Departamento de Amazonas, Colombia, likely have incorrect locality information as is the case with the other lots of various species discussed by Ballen (2011: 394).

Remarks. Steindachner (1911: 373) cited the type locality of Ancistrus fuesslii as Ostkolumbien, Sosomoco, 800 m Höhe (= eastern Colombia, Sosomoco, $800 \mathrm{~m}$ elevation), without information on the collector. The collector apparently was A. H. Fassl who also sampled lepidopterans during 1911 at that location in the east of the Departamento de Meta, Colombia (Holzinger \& Brown, 1982: 26; Salazar-E., 2008: 148). The species name (füsslii) appears to be a printer's lapsus for the collector's name (Fassl) since Steindachner applied the correct patronymic to a species of Trichomycterus (Pygidium fasslii, Ferraris, 2007: 418). Sosomoco is an apparent incorrect citation of quebrada Susumuco in the east of the Departamento de Meta with that stream running through the adjoining Departamento de Cundinamarca to the río Negro upstream of Villavicencio (Maldonado-Ocampo et al., 2005: 154; Salazar-E., 2008: 148). The location cited as Sumico (CAS 58795) in the material examined may also be an erroneous citation of Susumuco.

Type localities for Ancistrus fuesslii and Pseudancistrus pediculatus lie very close to each other in the same basin in the western reaches of the río Orinoco. Examination of the type series of both nominal species supplemented by an extensive series of other specimens in that area failed to reveal differences between the nominal forms and we place Pseudancistrus pediculatus as a subjective junior synonym of Ancistrus fuesslii (the Dolichancistrus fuesslii of this study).

Eigenmann was apparently unaware of Steindachner's (1911) description of Ancistrus füsslii, a species he neither cited in his account of Pseudancistrus pediculatus (1917) nor in his monographic study of the fishes of northwestern South America (Eigenmann, 1922). This oversight was universal until Isbrücker's (1980: 44) assignment of the species to Lasiancistrus.

Eigenmann (1922: 79) reported Pseudancistrus pediculatus (= Dolichancistrus fuesslii herein) from the Pacific versant rio Tamaná, a drainage distant from the known range of the species east of the Andes. Examination of the specimen (CAS 58792; formerly IU 13655) confirms it is an immature Dolichancistrus and possibly D. fuesslii. The only species of the genus known from rivers of the Pacific slope is $D$. atratoensis which, however, differs from the Eigenmann specimen in multiple details. This raises the question of erroneous locality information for the specimen, a possibility noted by Eigenmann (1922: 79). The specimen was acquired by Eigenmann from "Mr. W. F. H. Rosenberg" who collected at a numerous localities in northwestern South America. The secondary nature of the information increases the possibility that the locality data is incorrect.

\section{Acknowledgements}

Research associated with this project was supported by the Office of the Associate Director of Research and the Robert $\mathrm{H}$. Gibbs Memorial Fund at the National Museum of Natural History, Smithsonian Institution. We thank Mark Sabaj Perez and John Lundberg (ANSP), Jonathan Armbruster and David Werneke (AUM), James Maclaine (BMNH), Carlos Ardila (CAR), David Catania (CAS), Luz Fernanda Jiménez (CIUA), Francisco Villa (CZUT-IC), Mary Anne Rogers (FMNH), Claudia Medina (IAvHP), J. Iván Mojica (ICNMHN), Otto Castillo (MCNG), Brother José Espitia (MLS), Ernst Mikschi and Helmut Wellendorf (NMW), Sven Kullander (NRM), and Sandra Raredon (USNM) for the loan of specimens and other assistance. Gonzalo Andrade and Julio Betancur (ICNMHN) provided access to photographic equipment and Paola Triviño and Miguel Rodríguez provided assistance during photographic sessions. T. Britt Griswold prepared Figure 4. John D. Lynch (ICNMHN) is especially acknowledged for providing workspace and access to equipment and library facilities in addition to invaluable advice over the years to GAB. The paper benefitted from the comments of Carl J. Ferraris Jr., John D. Lynch, and Donald C. Taphorn.

Material Examined. Chaetostoma group: Chaetostoma anale, ANSP 70525 (holotype), ICNMHN 13397, 17364. C. dorsale, ICNMHN 1183, 3372, 3535, 7997, 8011, 8013, 8027, 8031, 17499, 17646, MLS 588, 747, 604. C. jegui, INPA uncataloged (photograph). C. loborhynchos, MUSM 20291 (photograph). C. milesi, ANSP 69330 (holotype), ICNMHN 10420, 15528, 16123, 16268, 16291, MLS 562. C. pearsei, ICNMHN 10361. C. platyrhynchum, ICNMHN 5488, 7971, 9417, 17624, 17625, 17626, 17628, 17629, 17630, 17631. C. sovichthys, ICNMHN 2381, 16223, MLS 568, 590, 600, USNM 121053 (photograph, radiograph, holotype). C. tachiraense, MLS 797, 799, 805, USNM 121052 (photograph, radiograph, holotype). Chaetostoma sp., AUM 45597, 45634. Cordylancistrus daguae, ICNMHN 3515, 17643, 17644, 17645. C. perijae, ANSP 168917 (paratype), ICNMHN 17502 (formerly CAR 270, formerly MBUCV-V 21745, paratype). C. platycephalus, BMNH (photograph of holotype). Cordylancistrus sp. 1, ICNMHN 17503 (formerly CAR 370), MLS 541. Cordylancistrus sp. 2, BMNH 1908.5.29.70-79. Cordylancistrus sp. 3, CP-UCO 1060, 1062. Cordylancistrus sp. 4. FMNH 76213 (cs). C. torbesensis, USNM 121001 (radiograph, holotype). Leptoancistrus 
canensis, USNM 78300 (radiograph, paratypes). Leptoancistrus sp., CIUA 774, 775, 776, 777, 778, 779, 780, 781. Incertae sedis: Chaetostomus setosus, BMNH 1880.2.26.9-10, syntypes, 2, CIUA 698, 4 (51.04-70.82 mm SL), ICNMHN 1158, 5. Remainder of Ancistrini. Ancistrus centrolepis, IAvH-P 10473, ICNMHN 104, 189, 1632, 3153. A. martini, ICNMHN 1206, 17647, 17648, 17653. A. triradiatus ICNMHN 17649, 17654. Baryancistrus niveatus, MNRJ 19344. Dekeyseria niveata, ANSP 185259. D. pulcher, ANSP 185298. D. scaphirhyncha, ICNMHN 12787, 12788. Hemiancistrus guahiborum, ICNMHN 5323, 11915. H. punctulatus, ANSP 170168. H. sabaji, ANSP 185153. Hopliancistrus tricornis, AUM 39853. Hypancistrus contradens, ICNMHN 11917, 11918. H. debilittera, ICNMHN 10691. Lasiancistrus caucanus, ICNMHN 8763. L. guacharote, ICNMHN 16916. Leporacanthicus galaxias, AUM 42144. L. triactis, ZMA 120774. Lithoxus jantjae, ANSP 182809 (paratypes). L. lithoides, ANSP 39121 (paratype). Megalancistus aculeatus, USNM 52594. Neblinichthys pilosus, ANSP 157587 (paratypes). N. roraima, ANSP 174914 (paratypes). Panaque maccus, ICNMHN 15728. P. cochliodon, ICNMHN 369. Peckoltia bachi, ICNMHN 13952. P. brevis, ICNMHN 7952. P. vittata, ICNMHN 7954, 12792. Pseudacanthicus leopardus, AUM 35550, USNM 197105. P. spinosus, USNM 52594. Pseudancistrus sidereus, ANSP 185297. Pseudolithoxus dumus, ANSP 185255. Spectracanthicus punctatissimus, MNHN 1999-0021.

\section{Literature Cited}

Armbruster, J. W. 2003. Peckoltia sabaji, a new species from the Guyana Shield (Siluriformes: Loricariidae). Zootaxa, 344: $1-12$.

Armbruster, J. W. 2004a. Phylogenetic relationships of the suckermouth armored catfishes (Loricariidae) with emphasis on the Hypostominae and the Ancistrinae. Zoological Journal of the Linnean Society, 141: 1-80.

Armbruster, J. W. 2004b. Pseudancistrus sidereus, a new species from southern Venezuela (Siluriformes: Loricariidae) with a redescription of Pseudancistrus. Zootaxa, 628: 1-15.

Armbruster, J. W. 2008. The genus Pecklotia with the description of two new species and a reanalysis of the phylogeny of the genera of the Hypostominae (Siluriformes: Loricariidae). Zootaxa, 1822: 1-76.

Armbruster, J. W., N. K. Lujan, \& D. C. Taphorn. 2007. Four new species of Hypancistrus from southern Venezuela (Siluriformes: Loricariidae). Copeia, 2007: 62-79.

Armbruster, J. W \& D. C. Taphorn, 2011. A new genus and species of weakly armored catfish from the upper Mazaruni River, Guyana (Siluriformes: Loricariidae) Copeia, 2011: 46-52.

Ballen, G. A. 2011. A new species of Chaetostoma Tschudi (Siluriformes: Loricariidae) from Colombia with a definition of the $C$. anale species group. Papéis Avulsos de Zoologia, 51: 383-398.

Boulenger, G. A. 1887. On new siluroid fishes from the Andes of Columbia. Annals and Magazine of Natural History, Series 5, 19: 348-350.

Burgess, W. E. 1989. An atlas of freshwater and marine catfishes. T. F. H. Publications, Inc. Neptune City, New Jersey, 784p.

Cala, P. 1981. Catalogo de los ejemplares tipo en la coleccion de peces del Instituto de Ciencias naturales. Museo de Historia Natural de la Universidad Nacional de Colombia. Lozania (Acta Zoologica Colombiana), 34: 1-8.

Dahl, G. 1960. New fresh-water fishes from western Colombia. Caldasia, 8: 451-484.
Dahl, G. 1971. Los Peces del Norte de Colombia. Instituto de Desarrollo de los Recursos Naturales Renovables, Bogotá, 391p.

Diccionario Geográfico de Colombia, 1996. Volume 2. Third edition, Instituto Geográfico Agustín Codazzi, Bogotá, 623p.

Eigenmann, C. H. 1916. New and rare fishes from South American rivers. Annals of the Carnegie Museum, 10: 77-86.

Eigenmann, C. H. 1917. Eighteen new species of fishes from northwestern South America. Proceedings of the American Philosophical Society, 56: 673-689.

Eigenmann, C. H. 1922. The fishes of western South America, Part I. - The fresh-water fishes of northwestern South America, including Colombia, Panama, and the Pacific slopes of Ecuador and Peru, together with an appendix upon the fishes of the Rio Meta in Colombia. Memoirs of the Carnegie Museum, 9: 1-346.

Eigenmann, C. H. \& R. S. Eigenmann. 1890. A revision of the South American Nematognathi or cat-fishes. Occasional Papers of the California Academy of Sciences, 1: 1-508.

Ferraris, C. J. Jr. 2007. Checklist of catfishes, recent and fossil (Osteichthyes: Siluriformes), and catalogue of siluriform primary types. Zootaxa, 1418: 1-628.

Ferraris, C. J., Jr. \& R. P. Vari. 1992. Catalog of type specimens of recent fishes in the National Museum of Natural History, Smithsonian Institution, 4: Gonornychiformes, Gymnotiformes, and Siluriformes (Teleostei: Ostariophysi). Smithsonian Contributions to Zoology, 535: 1-52.

Fisch-Muller, S. 2003. Ancistrinae. Pp. 373-400. In: R. E. Reis, S. O. Kullander, \& C. J. Ferraris Jr. (Eds.). Check list of the freshwater fishes of South and Central America. Edipucrs, Porto Alegre, Brazil, 727p.

Fowler, H. W. 1942. Lista de peces de Colombia. Revista de la Academia Colombiana de Ciencias Exactas, Fisicas y Naturales, 5: $128-138$.

Galvis, G., J. I. Mojica \& M. Camargo. 1997. Peces del Catatumbo. Asociación Cravo Norte, Ecopetrol, OXY \& Shell, Bogotá, 118p.

Geerinckx, T. \& D. Adriaens. 2006. The erectile cheek-spine apparatus in the bristlenose catfish Ancistrus (Loricariidae, Siluriformes), and its relation to the formation of a secondary skull roof. Zoology, 109: 287-299.

Geerinckx, T., M. Brunain, A. Herrel, P. Aerts \& D. Adriaens. 2007. A head with a suckermouth: a functional-morphological study of the head of the suckermouth armoured catfish Ancistrus cf. triradiatus (Loricariidae, Siluriformes). Belgian Journal of Zoology, 137: 47-66.

Gosline, W. A. 1945. Catálogo dos nematognatos de água-doce da América do Sul e Central. Boletim do Museu Nacional, Nova série, Zoologia, 33: 1-138.

Henn, A. W. 1928. List of types of fishes in the collection of the Carnegie Museum on September 1, 1928. Annals of the Carnegie Museum, 19: 51-99.

Hilty, S. L. \& W. L. Brown. 1986. A guide to the birds of Colombia. Princeton University Press, Princeton, New Jersey, 996p.

Holzinger, H. \& K. S. Brown, Jr. 1982. Zur kenntnis von Heliconus xanthocles Bates (Lepidoptera: Nymphalidae). Zeitschrift der Arbeitsgemeinschafte Österreichischen Entomologen, 34: 19-36.

Ibarra, M. \& D. J. Stewart. 1987. Catalogue of type specimens of recent fishes in Field Museum of Natural History. Fieldiana Zoology, New Series, 35: 1-112.

Isbrücker, I. J. H. 1980. Classification and catalogue of the mailed Loricariidae (Pisces, Siluriformes). Verslagen en Technische Gegevens, Instituut voor Taxonomische Zoölogie, Universiteit van Amsterdam, 22: 1-181.

Isbrücker, I. J. H. 2001. Nomenklator der Gattungen und Arten der 
Harnischwelse, Familie Loricariidae Rafinesque, 1815 (Teleostei: Ostariophysi). DATZ - Sonderheft, Harnischwelse, 2: 25-32.

Isbrücker, I. J. H. 2002. Nomenclator of the 108 genera with 692 species of the mailed catfishes, family Loricariidae Rafinesque, 1815 (Teleostei, Ostariophysi). Cat Chat, Journal of the catfish study group (UK), 3: 11-30.

Lasso, C. A., D. Lew, D. C. Taphorn, C. DoNascimiento, O. LassoAlcalá, F. Provenzano \& A. Machado-Allison. 2004a. Biodiversidad ictiologico continental de Venezuela. Parte 1. Lista de especies y distribución por cuencas. Memoria de la Fundación La Salle de Ciencias Naturales, 159-160 (for 2003): 105-195.

Lasso, C.A., J. I. Mojica, J. S. Usma, J.A. Maldonado, C. DoNascimiento, D. Taphorn, F. Provenzano, O. M. Lasso-Alcalá, G. Galvis, L. Vásquez, M. A. Lugo, R. Royero, C. Suárez \& A. Ortega-Lara. 2004b. Peces de las cuencas del río Orinoco. Parte I: lista de especies y distribucíon por subcuencas. Biota Colombiana, 5: 95-158.

Lujan, N. A., M. Arce, \& J. W. Armbruster. 2009. A new black Baryancistrus with blue sheen from the upper Orinoco (Siluriformes: Loricariidae). Copeia, 2009: 50-56.

Lujan, N. \& J. W. Armbruster. 2011. Two new genera and species of Ancistrini (Siluriformes: Loricariidae) from the western Guyana Shield. Copeia, 2011: 216-225.

Mago-Leccia, F. 1970. Lista de los peces de Venezuela, incluyendo un estudio preliminar sobre la ictiogeografía del país. Ministerio de Agricultura y Cria, Oficina Nacional de Pesca, Caracas, Venezuela, 283p.

Maldonado-Ocampo J. A., A. Ortega-Lara, J. S. Usma Oviedo, G. Galvis, F. Villa-Navarro, L. Vásquez, S. Prada-Pedreros, \& C. A. Rodríguez. 2005. Peces de los Andes de Colombia. Guía de campo. Instituto de Investigación de Recursos Biológicos “Alexander von Humboldt,” Bogotá, Colombia, 346p.

Maldonado-Ocampo, J. A., R. P. Vari \& J. S. Usma. 2008. Checklist of the freshwater fishes of Colombia. Biota Colombiana. 9: 143-237.

Maldonado-Ocampo, J. A., F. A. Villa-Navarro, A. Ortega-Lara, S. Prada-Pedreros, U. Jaramillo, A. Claro, J. S. Usma, T. S. Rivas, W. Chaverra, J. F. Cuesta \& J. E. García-Melo. 2006. Peces del río Atrato, zona hidrogeográfica del Caribe, Colombia. Biota Colombiana, 7: 143-154.

Miles, C. 1947. Los Peces del río Magdalena. Ministerio de la Economia Nacional; sección de piscicultura, pesca y caza, Bogotá, 214p.

Mojica, J. I., G. Galvis, P. Sánchez-Duarte, C. Castellanos \& F. A. Villa-Navarro. 2006. Peces del valle medio del río Magdalena, Colombia. Biota Colombiana, 7: 23-38.

Mojica, J. I. \& C. Castellanos-C. 2007. Colección de Ictiología. In: M. G. Andrade \& J. D. Lynch (Eds.). Los Tipos Nomenclaturales Depositados en la Colección Zoológica del Instituto de Ciencias Naturales. Biblioteca José Jeronimo Triana No. 16, Instituto de Ciencias Naturales, Universidad Nacional de Colombia, Bogotá, Colombia, 211p.

Moodie, G. E. E. \& M. Power. 1982. The reproductive biology of an armoured catfish, Loricaria uracantha, from Central America. Environmental Biology of Fishes, 7: 143-148.
Nijssen, H., L. van Tuijl \& I. J. H. Isbrücker. 1982. A catalogue of the type-specimens of recent fishes in the Institute of Taxonomic Zoology (Zoölogisch Museum), University of Amsterdam, The Netherlands. Verslagen en Technische Gegevens, Instituut voor Taxonomische Zoölogie, Universiteit van Amsterdam, 33: 1-173.

Provenzano, F., A. Marcano \& P. Mondaca. 1998. Catalogo de ejemplares tipos en la colección de peces del Museo de Biología de la Universidad Central de Venezuela (MBUCV-V). Acta Biologica Venezuelica, 18: 1-24.

Provenzano, F. \& N. Milani. 2006. Cordylancistrus nephelion (Siluriformes, Loricariidae), a new and endangered species of suckermouth armored catfish from the Tuy River, north-central Venezuela. Zootaxa, 1116: 29-41.

Regan, C. T. 1904. A monograph of the fishes of the family Loricariidae. Transactions of the Zoological Society of London, 17: 191-350.

Sabaj, M. H., J. W. Armbruster \& L. M. Page. 1999. Spawning in Ancistrus (Siluriformes: Loricariidae) with comments on the evolution of snout tentacles as a novel reproductive strategy: larval mimicry. Ichthyological Exploration of Freshwaters, 10: 217-229.

Salazar-E., J. A. 2008. Mariposas Colombianas X. Apuntes sobre la variación cromática en hembras de Pterourus cacicus Lucas, 1852 (Lepidoptera: Papilionidae). Boletin Cientifico Museo de Historia Natural, 12: 143-156.

Salcedo, N. J. 2006. Two new species of Chaetostoma (Siluriformes: Loricariidae) from the Huallaga river in central Perú. Ichthyological Exploration of Freshwaters, 17: 207-220.

Schultz, L. P. 1944. The catfishes of Venezuela, with descriptions of thirty-eight new forms. Proceedings of the United States National Museum, 94: 173-338.

Simons, F. A. 1881. On the Sierra Nevada of Santa Marta and its watershed (state of Magdalena, U. S. of Colombia). Proceedings of the Royal Geographical Society and Monthly Record of Geography, 3: 705-723.

Steindachner, F. 1911. Über einige neue und seltene südamerikanische Süsswasserfische. Anzeiger der Kaiserlichen Akademie der Wissenschaften, Mathematisch- Naturwissenschaftlichen Classe, 48: 369-376.

Taphorn, D., R. Royero, A. Machado-Allison \& F. Mago-Leccia. 1997. Lista actualizada de los peces de agua dulce de Venezuela, Pp. 55-100. In: E. La Marca (Ed.). Vertebrados Actuales y Fósiles de Venezuela. Museo de Ciencia y Tecnologia de Mérida, Mérida, Venezuela, 298p.

Taylor, W. R. \& G. C. van Dyke. 1985. Revised procedures for staining and clearing small fishes and other vertebrates for bone and cartilage study. Cybium, 9: 107-109.

Urbano-Bonilla, A., J. Zamudio, J. A. Maldonado-Ocampo, J. D. Bogotá-Grégory, G. A. Cortes-Millán \& Y. López. Peces del piedemonte del Departamento de Casanare, Colombia. Biota Colombiana 10: 149-162.

Submitted November 8, 2011

Accepted June 20, 2012

Published September 28, 2012 